\title{
Paleoclimate and weathering of the Tokaj (NE Hungary) loess-paleosol sequence: a comparison of geochemical weathering indices and paleoclimate parameters
}

\section{A.-K. Schatz, T. Scholten, and P. Kühn}

Soil Science and Geomorphology Group, Department of Geosciences, Faculty of Science, University of Tübingen, Rümelinstrasse 19-23, 72072 Tübingen, Germany

Received: 9 December 2013 - Accepted: 16 January 2014 - Published: 5 February 2014

Correspondence to: A.-K. Schatz (ann.schatz@uni-tuebingen.de)

Published by Copernicus Publications on behalf of the European Geosciences Union.

Paleoclimate and weathering of the Tokaj loess-paleosol sequence

A.-K. Schatz et al.

\section{Title Page}

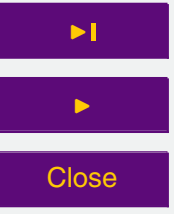

Full Screen / Esc 


\section{Abstract}

The Tokaj loess-paleosol sequence in NE Hungary is one of the key sites for detailed paleoclimate reconstructions of the Quaternary in SE Europe. In this study, the geochemical composition of samples from the upper part of the sequence (45-21 ka)

5 was analyzed and a variety of commonly used weathering indices and element ratios were applied to estimate weathering intensity. Further, similarities and differences between these weathering indices and their sensitivity to changes in paleoclimatic conditions were assessed. Results indicate that all of them accurately track changes in weathering intensity and are, with minor exceptions, very similar to each other.

Based on different transfer functions for major and trace element concentrations $(\mathrm{XRF})$, magnetic susceptibility (MS) and $\delta^{13} \mathrm{C}$ data, we calculated mean annual paleotemperature and mean annual paleoprecipitation for the time intervals of paleosol formation (45-27 ka) and dust deposition (27-21 ka). Results differ depending on the respective transfer function and method but largely agree with previously published 5 paleoclimate data of the region. XRF- and $\delta^{13} \mathrm{C}$-based results converge to a MAT of $8-10^{\circ} \mathrm{C}$ (paleosol) and $8-9^{\circ} \mathrm{C}$ (loess) and show a MAP range of $685-879 \mathrm{mma}^{-1}$ (paleosol) and 572-700 $\mathrm{mma}^{-1}$ (loess). MS-based results are most reliable with MATs of $8.4^{\circ} \mathrm{C}$ (paleosol) and $6.7^{\circ} \mathrm{C}$ (loess) and MAPs of $325-441 \mathrm{mma}^{-1}$ (paleosol) and $224 \mathrm{mma}^{-1}$ (loess).

\section{Introduction}

Loess paleosol sequences are important terrestrial archives of Quaternary climate changes (An et al., 1990; Catt, 1991; Catt et al., 2000; Kemp, 2001; Porter, 2001). Geochronological techniques have provided valuable insights into sediment dynamics and helped establish a general chronologic framework of loess-paleosol sequences as a basis for all subsequent climate studies. Geophysical and sedimentological methods, such as grain size analyses and magnetic susceptibility (Evans and Heller, 2001; Lu

\section{CPD}

$10,469-507,2014$

\section{Paleoclimate and weathering of the \\ Tokaj loess-paleosol sequence}

A.-K. Schatz et al.

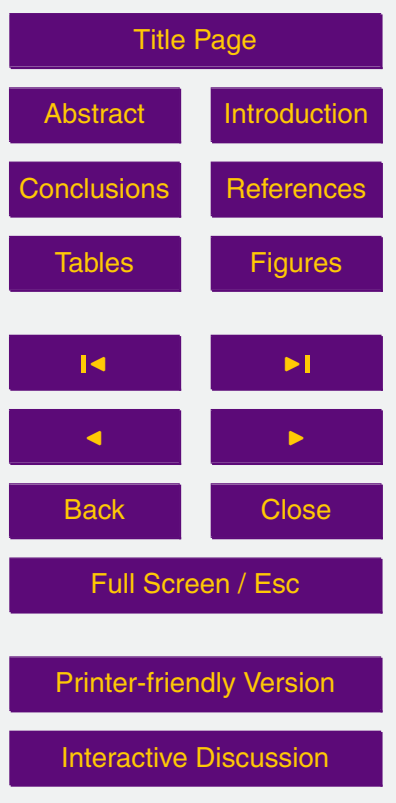

Interactive Discussion 
et al., 1999; Terhorst et al., 2014) have contributed to an improved understanding of past climate fluctuations, whereas paleontological findings have added unique paleoenvironmental information (Kovács et al., 2012; Sümegi and Krolopp, 2002). Spatially and temporally higher resolved micromorphological studies of soils and 5 sediments provide complementary insights to past climate, landscape and environment (Kühn et al., 2013; Pietsch et al., 2014). An additional source of more quantitative environmental and climate data are the wide range of organic geochemical methods such as biomarkers and stable isotopes (Hatté et al., 1999; Schatz et al., 2011; Zech et al., 2007, 2010).

10 Besides providing provenance information (Muhs et al., 2013; Újvári et al., 2008, 2014), loess and paleosol inorganic geochemistry generally reflects paleoweathering conditions and contributes to paleoclimate reconstructions as well. To quantify absolute and relative changes of paleoweathering intensity, a variety of different geochemical weathering indices (WIs) and element ratios have been introduced (Buggle et al., 15 2011; Sheldon and Tabor, 2009). Despite the debate about the reliability of these indices (Buggle et al., 2011; Li and Yang, 2010; Xiao et al., 2010), many successful applications can be found in the literature, mainly, but not limited to, Quaternary loess and paleosols in Europe (Buggle et al., 2011; Kovács, 2007; Kühn et al., 2013; Újvári et al., 2008, 2014; Vancampenhout et al., 2013), North and South America (Goldberg and Humayun, 2010; Hall and Penner, 2013; Meier et al., 2014), China (Baumann et al., 2014; Chen et al., 1999; Xiong et al., 2010), Southern Arabia (Pietsch and Kühn, 2012) and Siberia (Zech et al., 2008).

Yet weathering indices may not only serve to quantify paleoweathering intensity, but also to estimate paleoclimate parameters, i.e. mean annual temperature (MAT) and mean annual precipitation (MAP) via specifically calibrated empirical transfer functions (Sheldon and Tabor, 2009). Although having been published for several years, these transfer functions based on weathering indices (Sheldon and Tabor, 2009), magnetic susceptibility (Han et al., 1996; Maher et al., 1994) and stable carbon isotopes (Nordt et al., 2007) are still to gain more attention in loess-paleosol studies, especially for SE

\section{CPD}

10, 469-507, 2014

\section{Paleoclimate and weathering of the \\ Tokaj loess-paleosol sequence}

A.-K. Schatz et al.

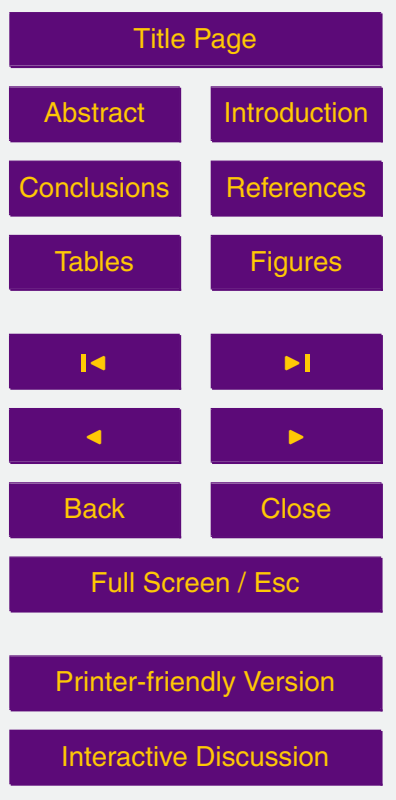

Interactive Discussion 
Europe since most successful studies have been conducted elsewhere (Kühn et al., 2013; Meier et al., 2014; Pietsch and Kühn, 2012).

Against this background, our study investigates one of the most extensively studied loess paleosol profiles in Tokaj, SE Hungary (NE Europe). The goals are (a) to 5 apply a variety of geochemical weathering indices and element ratios to estimate weathering intensity (b) to assess and compare similarities and differences between these weathering indices as well as their sensitivity to changes in paleoclimatic conditions and (c) to apply transfer functions to derive MAT and MAP estimates from different proxy records and to discuss and compare the results with local climate data 10 from the literature and the results of global climate models. The results of this study will broaden our understanding of the late Quaternary paleoclimate of SE Europe and contribute to the current debate about full-glacial refugia of thermophilous plants (Willis et al., 2000; Willis and van Andel, 2004). Furthermore, this study may serve as an encouragement of future applications of these methods to examine and quantify 15 paleoclimate records at other locations.

\section{Study area}

Tokaj (NE Hungary) is situated in the NE Carpathian Basin, a region of approximately $300000 \mathrm{~km}^{2}$ that is surrounded by major mountain ranges (Carpathian Mts., Alps, Dinaric Mts.; Fig. 1a). The area around Tokaj has been suggested as one of the 20 rare refuges for deciduous and coniferous trees during the last glacial and has, as a result, received considerable attention (e.g. Rudner and Sümegi, 2001; Schatz et al., 2011, 2012; Sümegi and Hertelendi, 1998; Sümegi and Rudner, 2001; Sümegi and Krolopp, 2002; Willis et al., 2000). Today, NE Hungary is part of the continental climate zone (Dfb, warm summer subtype), with a large seasonal temperature variance (mean January $T:-3^{\circ} \mathrm{C}$; mean July $T: 20.6^{\circ} \mathrm{C}$; mean annual $T: 9.8^{\circ} \mathrm{C}$ ) and a mean annual precipitation of $546 \mathrm{mma}^{-1}$ (World Data Center for Meteorology, 2011).

CPD

10, 469-507, 2014

\section{Paleoclimate and weathering of the \\ Tokaj loess-paleosol sequence}

A.-K. Schatz et al.

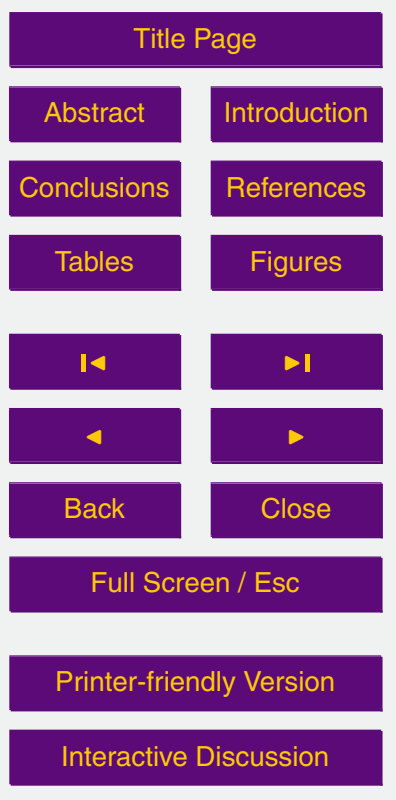


The loess-paleosol sequence at Patkó quarry is situated on the eastern slopes of Kopasz Hill (100 ma.s.I., $48^{\circ} 07^{\prime} \mathrm{N}, 21^{\circ} 24^{\prime} \mathrm{E}$ ), in the southernmost part of the Tokaj Mountains at the confluence of the Bodrog and Tisza rivers. A $15 \mathrm{~m}$ high loesspaleosol sequence with two well-developed paleosols and three loess layers is exposed 5 on top of an approximately $40 \mathrm{~m}$ high wall cut into the flanks of Kopasz Hill. The investigated section and the results of sedimentological, geochronological, geophysical and geochemical investigations have been described in detail by Sümegi and Rudner (2001), Sümegi and Hertelendi (1998) and Schatz et al. (2011, 2012). Since most paleoclimatic proxy data are only available for the upper half of the profile, i.e. the 10 upper loess layer and the upper paleosol, we concentrated primarily on this part of the section (Fig. 1b).

The upper paleosol developed on top of a ca. 50-60 ka old loess layer may correspond to the MIS3 "VL1L2" loess layer in the adjacent Vojvodina region in Serbia (Marković et al., 2008). It shows a reddish-brown, humic horizon with signs of podsolization in the upper part (Sümegi and Rudner, 2001), which may correspond to the Mende Upper 1 soil (MF1) in the Hungarian stratigraphic system (Pécsi, 1993). This soil formed in the latter stages of MIS3 between ca. 45 and $27 \mathrm{ka}$ and may be classified as a weakly developed type of "VL1S1" soil in the Vojvodina system. A charcoal layer directly on top of the paleosol, found in a similar stratigraphic position in an adjacent profile, was dated to 28-26 ka BP and has been interpreted as the result of extensive natural wildfires occurring after pedogenesis ceased and the climate became extremely dry (Sümegi and Hertelendi, 1998; Sümegi and Rudner, 2001). The upper loess layer was deposited in MIS 2 between 27 and $21 \mathrm{ka}$ and corresponds to the "VL1L1" loess. Dust deposition may have ceased afterwards, or younger loess may have been eroded or overprinted by pedogenesis. The recent soil is only weakly developed and affected by recent bioturbation; samples are not included in our analyses.

\section{CPD}

10, 469-507, 2014

\section{Paleoclimate and weathering of the \\ Tokaj loess-paleosol sequence}

A.-K. Schatz et al.

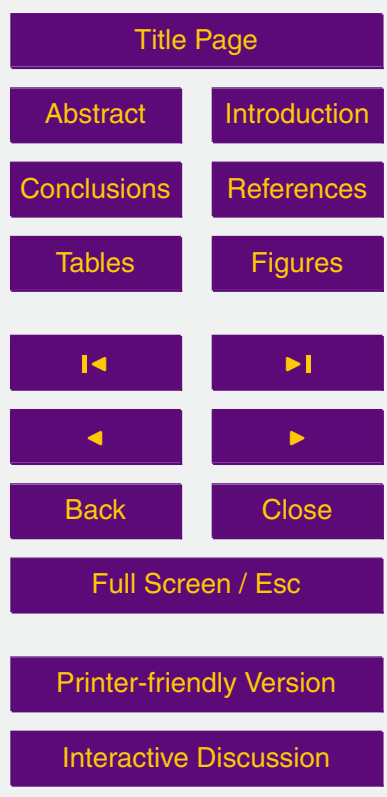




\section{Methods}

\subsection{Laboratory analyses}

35 bulk samples for geochemical analyses were taken in depth increments of $25 \mathrm{~cm}$ and air-dried at $40^{\circ} \mathrm{C}$. Total organic carbon (TOC) was measured on decalcified

5 subsamples $(50 \mathrm{mg}$ ) using an NA 1108 Elementar Analyzer (CE Instruments, Milan, Italy; BayCEER Lab, University of Bayreuth, Germany). $\mathrm{CaCO}_{3}$ was measured gasvolumetrically (DIN ISO 10693) and served as a basis for the calculation of total inorganic carbon (TIC). TIC and calcite-bound $\mathrm{CaO}$ were calculated stoichiometrically (wt.-\%):

$10 \mathrm{TIC}=\mathrm{CaCO}_{3} \cdot 0.12$

$\mathrm{CaO}_{\text {calcite }}=[(\mathrm{TIC} \cdot 3.6641)-(\mathrm{MgO} \cdot 2.092) \cdot 0.522] \cdot 2.2743 \cdot 0.5603$

$\mathrm{CaO}^{*}=\mathrm{CaO}_{\text {tot }}-\mathrm{CaO}_{\text {calcite }}$

In samples with low carbonate and high Mg concentrations (dolomite, mafic minerals), $15 \mathrm{CaO}_{\text {calcite }}$ calculations may yield negative results. In this case, values are set to 0 . Results are roughly similar to those obtained with McLennan's correction, which may support their validity. If $\mathrm{CaO}$ is corrected after McLennan (1993), the $\mathrm{CaO}^{*}$ (henceforth called $\mathrm{CaO}^{* *}$ ) concentration is calculated based on the ratio of $\mathrm{Ca}$ and $\mathrm{Na}$ : if the concentration of $\mathrm{CaO}$ is less or equal to the concentration of $\mathrm{Na}_{2} \mathrm{O}$, the $\mathrm{CaO}$ value remains unaltered. If the $\mathrm{CaO}$ concentration is higher than $\mathrm{Na}_{2} \mathrm{O}$, the $\mathrm{CaO}^{* *}$ value is set equal to $\mathrm{Na}_{2} \mathrm{O}$. Apatite-bound $\mathrm{Ca}$ is assumed to be negligible. Major and trace elements of ball-milled subsamples were analyzed with a Bruker AXS S4 Pioneer wavelength dispersive X-ray fluorescence spectrometer (ratio Li-metaborate: sediment $1: 5)$.

\section{CPD}

$10,469-507,2014$

\section{Paleoclimate and weathering of the \\ Tokaj loess-paleosol sequence}

A.-K. Schatz et al.

\section{Title Page}

\section{Full Screen / Esc}

Printer-friendly Version

Interactive Discussion 


\subsection{Weathering indices}

A variety of Wls were calculated (for formulae, see Table 1). Traditional, multi-element weathering indices are calculated from the concentrations of several mobile and immobile elements (in molar portions), thus providing a quantitative measure of mineral

5 weathering. They are usually based on the enrichment of Al and the depletion of cations as $\mathrm{Ca}, \mathrm{K}, \mathrm{Na}$ or Mg. Common multi-element WIs are $\Sigma$ Bases/Al ratio (Retallack, 2001) and, more recently, the Paleosol Weathering Index (PWI, Gallagher and Sheldon, 2013). Other ratios are based on a more limited selection of elements ( $\mathrm{Al}, \mathrm{K}, \mathrm{Na}, \mathrm{Ca}$ ) to focus on the weathering behavior of the feldspar group. An advantage of these feldspar indices is the fact that all index elements are hosted in the same mineral group, which helps minimizing the effects of variations in mineralogy. Common feldspar indices are the widely used Chemical Index of Alteration (CIA, Nesbitt and Young, 1982) and the Indices A and B after Kronberg and Nesbitt (1981).

In order to exclude potential effects arising from the inconsistency in $\mathrm{K}$ weathering 15 (Buggle et al., 2011), several indices without $\mathrm{K}$ were developed, most prominently the Chemical Index of Weathering (CIW, also called CIA-K, Harnois, 1988), which is the K-free equivalent of the CIA, and the Plagioclase Index of Alteration (PIA, Fedo et al., 1995), a further modification of CIA and CIW that adjusts for Al contained in K-feldspar and results in purely plagioclase weathering. The WI after Yang et al. (2006) uses Ti instead of Al as a refractory element and has been developed specifically for loesspaleosol studies, whereas WI-1 and WI-2 after Darmody et al. (2005) have not been widely applied to loess and paleosols yet.

Due to problems associated with determining the correct amount of silicate-bound $\mathrm{Ca}$, indices that do not rely on Ca might be preferable, such as the index of Feng (1997) or the Chemical Proxy of Alteration (CPA, also known as CIW', Cullers, 2000; Buggle et al., 2011), which factors out both $\mathrm{Ca}$ and $\mathrm{K}$, thus attempting to avoid all potential biases due to these cations.

\section{CPD}

10, 469-507, 2014

\section{Paleoclimate and weathering of the \\ Tokaj loess-paleosol sequence}

A.-K. Schatz et al.

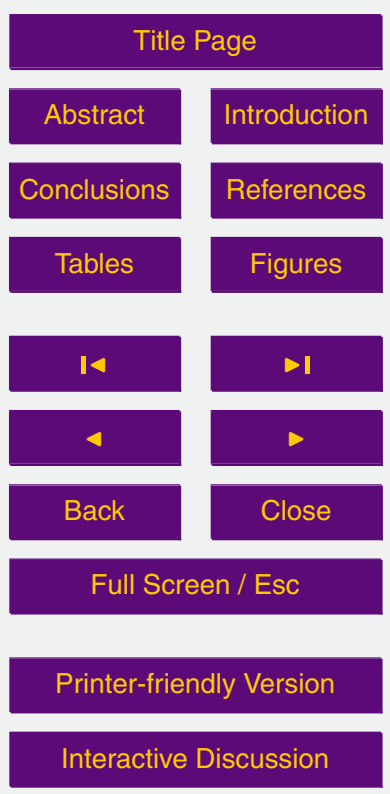


Trace element indices are the last group of commonly employed weathering indices (Table 1). Both $\mathrm{Ba} / \mathrm{Sr}$ and $\mathrm{Rb} / \mathrm{Sr}$ represent leaching behavior during weathering with $\mathrm{Ba}$ and $\mathrm{Rb}$ being less soluble than Sr. Potential weakness in these indices are the poorly understood behavior of $\mathrm{Rb}$ and $\mathrm{Ba}$ in the sediment (Gallet et al., 1996; Sheldon 5 and Tabor, 2009) and the fact that variable and low initial concentrations may result in erroneously high weathering intensities. In addition to that, $\mathrm{Sr}$ substitutes for $\mathrm{Ca}$ (Wedepohl, 1987) and is therefore controlled by calcite and dolomite behavior.

\subsection{Paleoclimate information}

Some of the weathering indices listed above may also be used to estimate 10 paleoprecipitation and paleotemperature based on empirical relationships between MAT or MAP and the geochemical composition of soils, usually using data from large soil databases (Marbut, 1935) and modern climate data. The equations were developed for $\mathrm{B}$ horizons of paleosols developed in different substrates. Taking into account that loess is the parent material of these horizons, the equations may be applied to loess as well, as proposed by e.g. Kühn et al. (2013) and Varga et al. (2011). In this study, we calculated MAP in three different ways after Sheldon et al. (2002). MAT was calculated after Sheldon et al. (2002), Sheldon (2006) and Gallagher and Sheldon (2013). Some methods are recommended for specific soil types (Table 2), e.g. forest soils. For comparison, we also calculated paleotemperature and paleoprecipitation 20 based on mass-specific magnetic susceptibility (MS) following Maher et al. (1994) and Han et al. (1996), and $\delta^{13} \mathrm{C}$-based paleotemperature of the paleosol (Nordt et al., 2007); both MS and isotopic data were obtained from the same samples (Schatz et al., 2011). Equations of all transfer function used in this study can be found in Table 2.

\section{CPD}

$10,469-507,2014$

\section{Paleoclimate and weathering of the \\ Tokaj loess-paleosol sequence}

A.-K. Schatz et al.

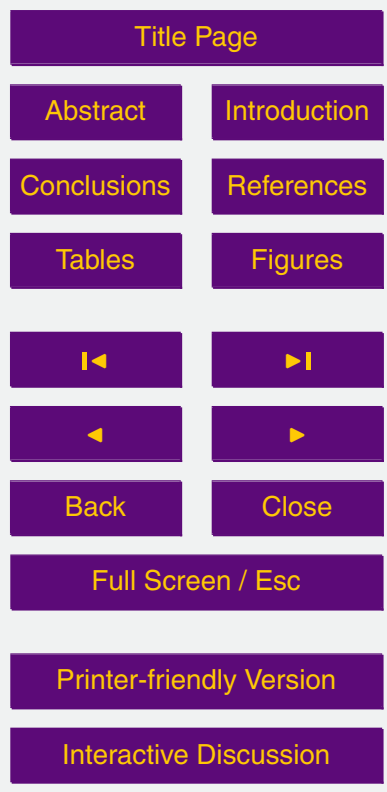




\section{Results}

\subsection{General geochemistry}

Loss on ignition (LOI, see Table S1 in the Supplement) reflects variable amounts of carbonate, hydrous phases (e.g. clay minerals) and organic matter in the samples.

5 Average LOI of the Tokaj samples is $6.48 \mathrm{wt}$. $\% \pm 0.83$; highest LOI tends to be found in loess, paleosol samples have overall lower values. There is a positive correlation of $\mathrm{LOI}$ with $\mathrm{CaCO}_{3}$ and $\mathrm{CaO}$ ( $r=0.66$ and 0.73 , respectively), indicating that $\mathrm{LOI}$ is mainly associated with carbonates. Average total inorganic carbon (TIC) is $0.56 \mathrm{wt}$. $-\% \pm 0.32$; average values are higher for loess than for paleosol samples, whereas organic 10 carbon (TOC; $\varnothing 0.15$ wt. $-\% \pm 0.33$ ) is lower in loess. $\mathrm{CaCO}_{3}(4.71$ wt. $-\% \pm 2.63)$ is higher in loess (5.88wt. - \%) than in paleosol samples (1.77 wt. - \%). Carbonate is strongly correlated with uncorrected $\mathrm{CaO}(r=0.99)$, indicating that $\mathrm{CaO}$ contents are strongly dependent on $\mathrm{CaCO}_{3}$, therefore, a correction is needed to obtain noncalcitic, silicate-bound $\mathrm{CaO}^{*}$ only. Uncorrected $\mathrm{CaO}$ is highly negatively correlated with $\mathrm{CaO}$-based weathering indices such as $\mathrm{CIA}(r=-0.99)$, which suggests that $\mathrm{CIA}$ variation is strongly influenced by uncorrected $\mathrm{CaO}$ and hence by $\mathrm{CaCO}_{3}$, instead of reflecting a change in non-calcitic $\mathrm{CaO}$. If corrected, the correlation coefficients of $\mathrm{CaO}^{*}$ and $\mathrm{CaCO}_{3}$ decrease $\left(\mathrm{CaO}^{*} / \mathrm{CaCO}_{3}: r=0.90, \mathrm{CaO}^{*} / \mathrm{CIA}: r=-0.95\right)$. Corrected $\mathrm{CaO}$ values differ systematically according to the correction method used. Measured $20 \mathrm{CaO}^{*}$ values range from $2.17 \mathrm{wt}$ - $\%$ to $3.85 \mathrm{wt}$ - $\%$ (Ø $2.92 \mathrm{wt}$. $-\% \pm 0.4$; loess: 3.02 wt. - \%, paleosol: 2.68 wt. - \%). Using McLennan's (1993) correction method, $\mathrm{CaO}^{* *}$ is significantly lower, ranging from $0.65 \mathrm{wt}$. $-\%$ to $1.83 \mathrm{wt} .-\%(\varnothing 1.50 \mathrm{wt}$. $-\% \pm$ 0.37 , loess: 1.63 wt. $-\%$, paleosol: $1.18 w t . \%$ ).

\subsection{Major elements}

25 The values of the major elements were recalculated on a volatile-free basis (Table S1). Compared with average loess composition ( $\mathrm{AVL}^{3}$, Újvári et al., 2008)
CPD

$10,469-507,2014$

\section{Paleoclimate and weathering of the \\ Tokaj loess-paleosol sequence}

A.-K. Schatz et al.

\section{Title Page}


and literature data, the samples contain a rather high amount, but narrow range, of $\mathrm{SiO}_{2}$ (73.4wt. $-\% \pm 1.4$ ), above-average amounts of $\mathrm{Al}_{2} \mathrm{O}_{3}(12.20 \mathrm{wt} . \% \pm 0.52), \mathrm{TiO}_{2}$ (0.88wt. $-\% \pm 0.04)$ and $\mathrm{Fe}_{2} \mathrm{O}_{3}(4.26$ wt. $-\% \pm 0.21)$, while $\mathrm{MgO}(1.78$ wt. $-\% \pm 0.24)$, $\mathrm{Na}_{2} \mathrm{O}(1.84$ wt. $-\% \pm 0.07)$ and $\mathrm{K}_{2} \mathrm{O}(2.11 \mathrm{wt} . \% \pm 0.14)$ contents are comparable to 5 or slightly below average. Down-section compositional variability among samples is low to moderate. Paleosols can be differentiated from loess by slightly higher contents of $\mathrm{SiO}_{2}$ (74.3 wt. - \% vs. 73.11 wt. $\left.-\%\right), \mathrm{Al}_{2} \mathrm{O}_{3}$ (12.88 wt. - \% vs. 11.9 wt. $\left.-\%\right)$ and $\mathrm{Fe}_{2} \mathrm{O}_{3}(4.5 \mathrm{wt} . \%$ vs. $4.2 \mathrm{wt} . \%)$ and slightly lower contents of $\mathrm{MgO}(1.5 \mathrm{wt} . \%$ vs. 1.9 wt. $-\%$ ), $\mathrm{CaO}^{*}\left(2.68\right.$ wt. $-\%$ vs. 3.02 wt. $-\%$ ) and $\mathrm{Na}_{2} \mathrm{O}$ (1.8wt. $-\%$ vs.

101.9 wt. - \%). In addition, paleosol samples have substantially lower $\mathrm{CaCO}_{3}$ values than loess. The chemical differences between loess and paleosol samples are similar to the results of other studies and were probably caused by dissolution of soluble/mobile elements during pedogenesis.

\subsection{Weathering} $X / Y$ elemental plots. In Fig. $2 \mathrm{a}-\mathrm{C}, \mathrm{Al}_{2} \mathrm{O}_{3} / \mathrm{SiO}_{2}, \mathrm{Fe}_{2} \mathrm{O}_{3} / \mathrm{TiO}_{2}$ and $\Sigma \mathrm{Bases} / \mathrm{TiO}_{2}$ plots illustrate the relative enrichment of $\mathrm{Al}$ and $\mathrm{Fe}$ during pedogenesis, whereas bases are depleted during the process. This depletion is further illustrated in the $\mathrm{Na}_{2} \mathrm{O} / \mathrm{Al}_{2} \mathrm{O}_{3}$ vs. $\mathrm{K}_{2} \mathrm{O} / \mathrm{Al}_{2} \mathrm{O}_{3}$ plot (Fig. 2d), Garrels and Mackenzie (1971), which shows that chemical 20 weathering leads to the removal of more soluble components such as $\mathrm{Na}$ and $\mathrm{K}$ compared to UCC and $\mathrm{AVL}^{3}$ (i.e. lower left corner), but also within the Tokaj dataset with paleosol samples being more depleted than loess samples.

The Tokaj samples plot in the A-CN-K diagram (Fig. 2f; Nesbitt and Young, 1984) in a less-weathered region compared to PAAS (Taylor and McLennan, 1985) and NASC 25 (Gromet et al., 1984) - both are standard samples for weathered continental sediments - and nearly parallel to the $\mathrm{A}-\mathrm{CN}$ line, i.e. they follow the plagioclase weathering trend with a constant $\mathrm{K}$-feldspar/plagioclase ratio. The degree of weathering is variable, with paleosol samples plotting closer to the $\mathrm{CN}$ corner and PAAS, indicating the progressive

\section{CPD}

$10,469-507,2014$

\section{Paleoclimate and weathering of the \\ Tokaj loess-paleosol sequence}

A.-K. Schatz et al.

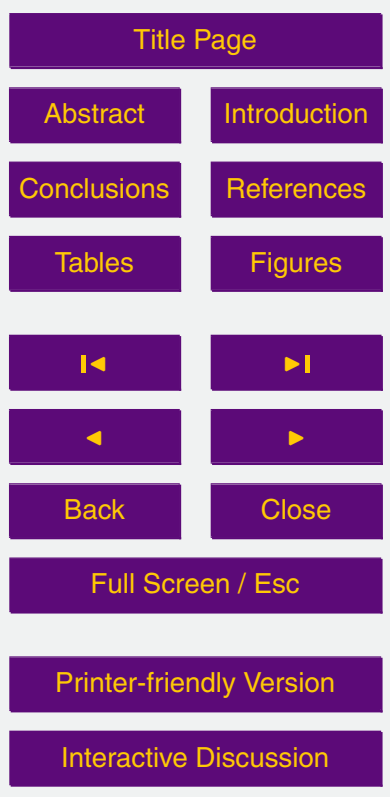

Interactive Discussion 
enrichment of $\mathrm{Al}$ and depletion of $\mathrm{Ca}$ and $\mathrm{Na}$ (plagioclase weathering) with increasing weathering intensity, while the $\mathrm{K}$ content (K-feldspar, micas) remains constant. The weathering trend originates close to the UCC composition (Taylor and McLennan, 1985), which equals a granodioritic composition and suggests that the samples have 5 been derived from a felsic source, which has most likely remained constant over time. The location of the samples in the A-CN-K diagram changes if $\mathrm{CN}$ is calculated with $\mathrm{CaO}^{* *}$ based on McLennan's correction instead of the measured $\mathrm{CaO}^{*}$ values. This underestimation results in a shift along the plagioclase weathering trend towards the $\mathrm{CN}$ corner, parallel to the A-CN line. However, both datasets still plot on a line between 10 UCC and PAAS, comparable with other paleosol and loess samples in the literature (Újvári et al., 2008, 2014; Buggle et al., 2011). Since the weathering trend is the same, an uncertainty in $\mathrm{CaO}$ composition does not affect the interpretation.

14 weathering indices were calculated (Table 1, Fig. 3) and compared with literature data. As most published weathering index data are predominantly based 15 on McLennan's $\mathrm{CaO}$ correction, both $\mathrm{CaO}^{*}$ and $\mathrm{CaO}^{* *}$-based values are listed in Table 1. The comparison shows that CIA, CIW, CPA, Index B, PIA and Yang results are comparable to those of other loess studies, with the exception of Varga et al. (2011), who tend to report values associated with a higher degree of weathering. The results of Kovács (2007) clearly deviate from the Tokaj results since Red Clay is stronger weathered than paleosols and loess. $\mathrm{AVL}^{3}$ generally shows less intense weathering but some indices are similar (CIW, WI-2), depending on the elements used for calculation.

Whereas the absolute results of the weathering indices calculated with either $\mathrm{CaO}^{*}$ or $\mathrm{CaO}^{* *}$ differ systematically, the shape of the WI depth plots, i.e. the relative changes of weathering intensity, does not vary much (Fig. 3e). Correlation is between $r=0.93$ (ClA-K) and $r=0.98$ (WI-1). Hence, for comparisons regarding relative changes in weathering intensity due to pedogenesis and climatic variations, the uncertainty introduced by different $\mathrm{CaO}$ corrections is negligible. For comparisons of absolute $\mathrm{WI}$ values, however, caution is required, as the results differ depending on the $\mathrm{CaO}$

\section{CPD}

$10,469-507,2014$

\section{Paleoclimate and weathering of the \\ Tokaj loess-paleosol sequence}

A.-K. Schatz et al.

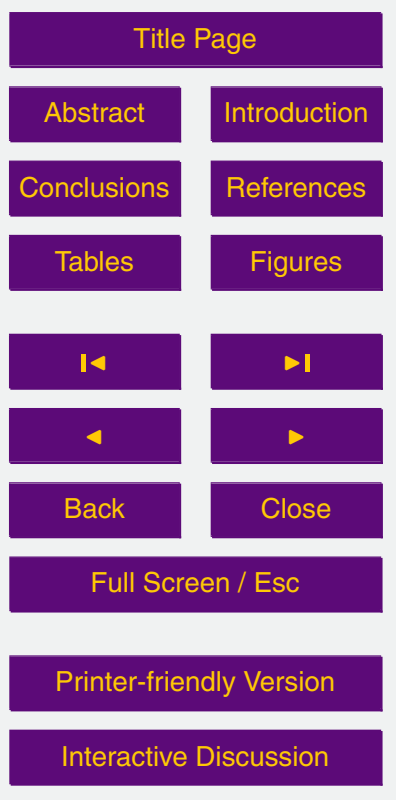


correction used. To further illustrate this observation, $\mathrm{CIA}\left(\mathrm{CaO}^{*}\right)$ and $\mathrm{CIA}\left(\mathrm{CaO}^{* *}\right)$ are shown in Fig. 2e.

A large group of WI plots are surprisingly parallel and have correlation coefficients of well above 0.85 (CIA, CIA-K, PIA, CALMAG, Index B, Yang, Feng, $\Sigma$ Bases/AI, Rb/Sr, $5 \mathrm{Ba} / \mathrm{Sr}$; Table 3). A second group of highly correlated WIs $(r>0.95)$ with similar shape includes WI-1, WI-2 and Index A; CPA and particularly PWI are least correlated with the other indices.

\subsection{Paleoclimatic data}

Results of MAP are generally in a range of several hundred $\mathrm{mma}^{-1}$ and $6-15^{\circ} \mathrm{C}$ for all methods and equations (Table 2 ). Absolute values vary substantially depending on the method used and the sample material. Paleosols have consistently higher MAP $\left(\Delta=200-300 \mathrm{mma}^{-1}\right)$ and MAT $\left(\Delta=0.5-2^{\circ} \mathrm{C}\right.$; Table 2$)$. MS-based MAP is significantly lower than WI-based MAP, while MAT values agree within error, except MAT-3 (Gallagher and Sheldon, 2013), which yields much higher temperature and precipitation. Both MAP and MAT calculated from geochemical and MS data show warmer and wetter conditions during the time of paleosol formation ( 45-27 ka) and colder, drier climate during dust deposition in MIS 2 (27-21 ka), including the LGM. XRF3-MAT is an exception as it shows only minor temperature shifts between warmer and colder periods, as well as much higher absolute temperatures. Both XRF3-MAP and XRF3-MAT seem erroneously high, especially if compared to literature data (see below), and are therefore excluded from further interpretations.

\section{CPD}

$10,469-507,2014$

\section{Paleoclimate and weathering of the \\ Tokaj loess-paleosol sequence}

A.-K. Schatz et al.

\section{Title Page}

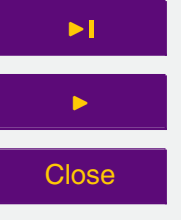




\section{Discussion}

\subsection{Comparison of weathering indices, recommendations and the $\mathrm{CaO}^{*}$ controversy}

The majority of WIs is highly correlated (Table 3), indicating that there are equally able 5 to detect changes in the weathering intensity within the Tokaj loess-paleosol sequence. Anomalies and divergences associated with the use of $\mathrm{K}$ in these equations, resulting in differences between K-free and K-based indices, cannot be observed in our dataset. This might be due to the stronger weathering resistance of K-bearing minerals in low to moderately weathered samples and to the predominance of plagioclase (K-free feldspar) in the Tokaj samples, as inferred from the $\mathrm{A}-\mathrm{CN}-\mathrm{K}$ diagram. If $\mathrm{Ca}$ is corrected for calcite-bound $\mathrm{Ca}$, as discussed above, Wls are not biased by $\mathrm{CaCO}_{3}$ content and yield more reliable results, similar to Ca-free indices as FENG. Thus, as long as any type of correction is applied, it is not necessary to use Ca-free indices. While we do acknowledge the geochemical considerations that led to the recommendations of $\mathrm{K}$ - and Ca-free indices, our results indicate that that these limitations might be overcautious. It is even possible that, by limiting an index to very few contributing elements such as $\mathrm{Al}$ and $\mathrm{Na}$ in the CPA, specific element concentrations, as e.g. introduced by secondary Na-salts at sites with negative water balance, are easily overemphasized and may lead to a bias in the results (Baumann et al., 2014).

20 Table 3 shows that the two Wls based on trace elements are highly correlated with the majority of the Wls based on main elements. The ratios $\mathrm{Ba} / \mathrm{Sr}$ and $\mathrm{Rb} / \mathrm{Sr}$ are frequently used in paleosol and loess weathering studies (e.g. Chen et al., 1999; Varga et al., 2011). There is, however, an ongoing debate about the reliability of trace element indices due to a lack of understanding of their weathering behavior, especially under
CPD

10, 469-507, 2014

\section{Paleoclimate and weathering of the \\ Tokaj loess-paleosol sequence}

A.-K. Schatz et al.

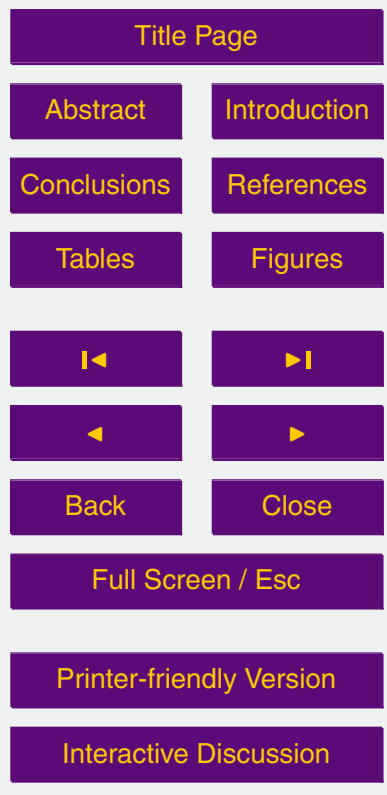


There are two subgroups of Wls which, although moderately to well correlated with other indices, show slightly different depth plots. WI-1, WI-2 and Index A indicate a decrease in weathering intensity of $2.5-4.0 \mathrm{~m}$ in the L1L1 loess layer that is not displayed by the main group of WIs. All three indices include $\mathrm{Si}$ as an additional element in their calculations, which might explain this minor deviation and decrease in correlation coefficients $(r=0.8-0.85)$. PWI and, to a lesser extent, CPA are particularly weakly correlated with all other indices. Both indices point to an increase in weathering intensity of $1.75-2.25 \mathrm{~m}$ and seem to underestimate the weathering intensity of the upper half of the paleosol, which is significantly lower than that of the lower half. This might be due to the relative overemphasis of $\mathrm{Na}$ in the equations.

\subsection{Sensitivity of weathering indices}

In order to decide which WI is "correct", i.e. which weathering index is most sensitive to variations in the paleoweathering intensity, a comparison with other weatheringrelated proxy data may provide support. The validation step has not been included 5 in previous studies, which demonstrated and discussed various WI data without examining correlations with other weathering proxies (e.g. Buggle et al., 2011; Varga et al., 2011). For Tokaj (using the same samples as in this study), Schatz et al. (2011) have published grain-size and magnetic susceptibility data. Both MS and grain size distribution are commonly applied as indicators of weathering intensity (Buggle et al., 2009; Marković et al., 2008; Terhorst et al., 2014). In addition, biomarkers and stable $\mathrm{C}$ and $\mathrm{N}$ isotopes as proxies of vegetation and climate dynamics are indirectly linked to weathering as well (Hatté et al., 2013; Schatz et al., 2011; Zech et al., 2010) but probably do not provide evidence for the sensitivity of weathering indices. Table 4 shows an overview of the correlation coefficients between the WIs and MS, grain size, stable $\mathrm{C}$ and $\mathrm{N}$ isotopes and alkane biomarkers. All WIs and proxies are moderately to well correlated and there is no single index that successfully matches all proxies, nor can one or more indices be rejected due to a weak correlation.

\section{CPD}

$10,469-507,2014$

\section{Paleoclimate and weathering of the \\ Tokaj loess-paleosol sequence}

A.-K. Schatz et al.

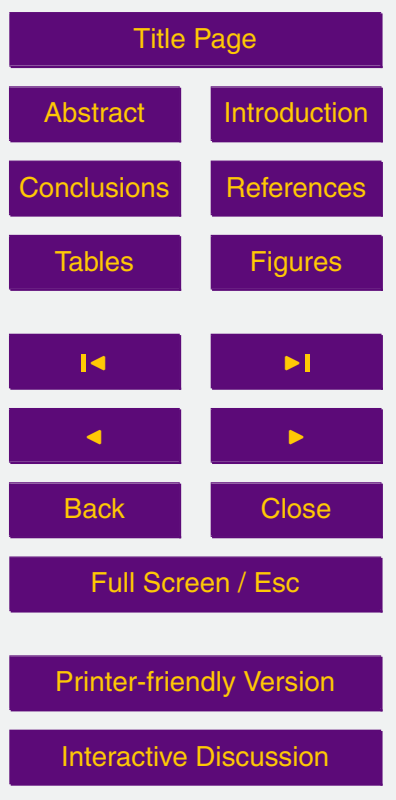


The highest correlation coefficients are found for those proxies that are directly linked with weathering intensity, i.e. grain size (fraction $>30 \mu \mathrm{m}$ ) and MS, with FENG and $\mathrm{Rb} / \mathrm{Sr}$ showing the highest correlations. For $\mathrm{MS}, \mathrm{Ba} / \mathrm{Sr}$ is highly correlated as well, and $\mathrm{WI}-1$ for grain size. CIA-K, CALMAG and PWI are the least successful indices 5 with $r$ between 0.66 and 0.72 . Wl-1 and $\mathrm{Rb} / \mathrm{Sr}$ (and CPA) are also well-correlated with stable $\mathrm{C}$ and $\mathrm{N}$ isotopes, and $\mathrm{FENG}$ (and $\mathrm{Ba} / \mathrm{Sr}, \Sigma \mathrm{Bases} / \mathrm{Al}$ ) with the percentage of shrubs and trees (alkane biomarkers).

Based on this evaluation of the sensitivity of different WIs, the use of FENG and $\mathrm{Ba} / \mathrm{Sr}$ is most desirable since these indices most accurately track changes in 10 weathering intensity. This is surprising because multi-element indices such as FENG have come under suspicion due to their reliance on elements such as $\mathrm{Na}$ and $\mathrm{Ca}$, which may bias results if secondary carbonates or $\mathrm{Na}$ salts are present (Baumann et al., 2014; Buggle et al., 2011). Trace-element indices such as $\mathrm{Rb} / \mathrm{Sr}$ have been deemed unsuitable due to the unstable weathering behavior of the immobile element

the Tokaj loess paleosol section, however, both indices yield the best results. This might be due to the fact that the profile is not affected by secondary $\mathrm{Na}$ salt formation and the correction for $\mathrm{Ca}$ in secondary carbonates by means of gasvolumetric $\mathrm{CaCO}_{3}$ measurements. $\mathrm{Rb}$, which may be mobilized under humid and high-intensity weathering conditions with clay translocation processes (Dultz, 2001; Fiedler et al., 1990; Kühn, 2003), has probably remained stable and can therefore be employed as a reliable immobile index element in combination with soluble and mobile Sr. An individual evaluation of the WI sensitivity and the suitability of the best-performing index is recommended for future loess paleosol studies at other locations since weathering conditions vary through time 25 and space.

\section{CPD}

$10,469-507,2014$

\section{Paleoclimate and weathering of the \\ Tokaj loess-paleosol sequence}

A.-K. Schatz et al.

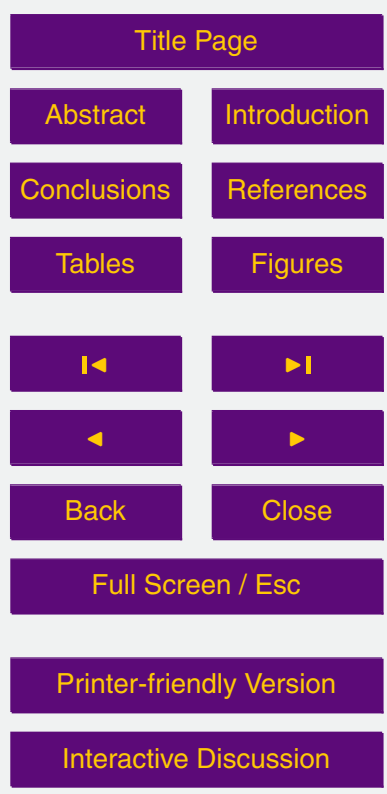




\subsection{Paleoclimatic reconstruction}

\subsubsection{Mean annual temperature (MAT)}

\section{MAT during the time of paleosol formation ( 45-27 ka)}

For this paleosol formation interval, geochemistry-based MAT results in a temperature 5 range of $8.8 \pm 0.6{ }^{\circ} \mathrm{C}$ (XRF1-MAT) to $9.9 \pm 4.4^{\circ} \mathrm{C}$ (XRF2-MAT). MS-MAT of $8.4^{\circ} \mathrm{C}$ is slightly lower, but mostly agrees within the XRF error limits (Table 2, Fig. 4a). Current MAT at the nearest weather station, Miskolc (Hungary), is $9.8^{\circ} \mathrm{C}$ with a mean July temperature of $20.6^{\circ} \mathrm{C}$ (1991-2000 average; World Data Center for Meteorology, 2011).

10 It has been proposed by various researchers that the Carpathian Basin was warmer and drier than elsewhere in Europe during MIS 3 and with patchy, mosaic-like variations in local climates, creating refugia for thermophilous species (Willis et al., 2000; Willis and van Andel, 2004; Fitzsimmons and Hambach, 2014). Regional paleotemperature estimates for this period of time are scarce, but Kovács et al. (2012) reported MATs isotope analyses of mammoth teeth enamel. Several studies in Hungary and Serbia using the malacothermometer method suggested mean July paleotemperatures of 19$21^{\circ} \mathrm{C}$ and MAT similar to that of today, i.e. around $10^{\circ} \mathrm{C}$ (Marković et al., 2007; Krolopp and Sümegi, 1995; Novothny et al., 2011; Sümegi and Krolopp, 2002). Sümegi and summer paleotemperatures of $14-18^{\circ} \mathrm{C}$ (malacothermometer) for Tokaj.

Further evidence might come from a $\delta^{13} \mathrm{C}$-derived mean July paleotemperature following Nordt et al. (2007), which is based on differences in the isotopic composition of $\mathrm{C} 3$ and C4 plants and their dependence on temperature and climate. This is the 25 first transfer function available for $\delta^{13} \mathrm{C}$ data and has successfully been applied to reconstruct paleotemperatures in semiarid grasslands (Hall and Penner, 2013; Meier et al., 2014). However, this function is probably not suitable for samples outside a temperature range of ca. $16.4-26^{\circ} \mathrm{C}$, i.e. minimum and maximum temperatures that 484

\section{CPD}

$10,469-507,2014$

\section{Paleoclimate and weathering of the \\ Tokaj loess-paleosol sequence}

A.-K. Schatz et al.

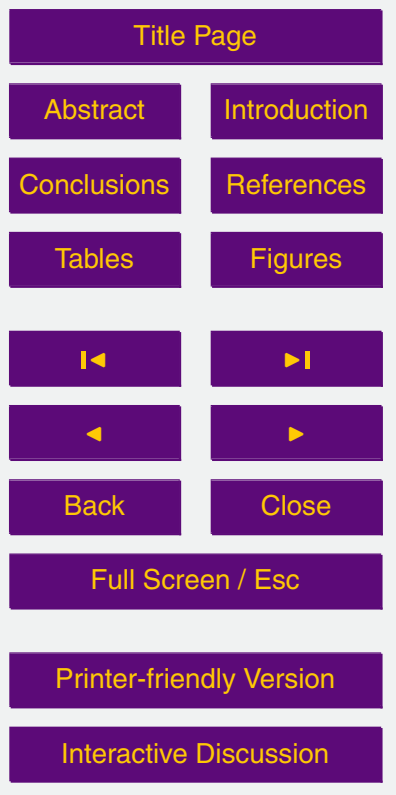


correspond to the highest and lowest naturally occurring plant $\delta^{13} \mathrm{C}$ values $(-13 \%$ 。 for $\mathrm{C} 4,-26 \%$ o for $\mathrm{C} 3$ plants). If applied to the $\delta^{13} \mathrm{C}$ data of the Tokaj paleosol (Schatz et al., 2011), which probably lies within this temperature range, a mean July paleotemperature of $18.0^{\circ} \mathrm{C}\left( \pm 1.14^{\circ} \mathrm{C}\right)$ can be derived that is consistent with previous 5 malacothermometer results.

A novel approach to convert mean July paleotemperatures into MAT has recently been proposed by Hall and Penner (2013). It requires a simple linear regression calculated from modern MAT and modern mean July temperature. We used input data from the Hungarian Meteorological Survey for the nearest weather station, Debrecen 10 (1901-2000, 10yr intervals; Hungarian Meteorological Service, 2013), and derived an empirical conversion formula following their approach $(y=0.3507 x+2.5117 ; r=$ 0.42). If applied to the present mean July temperature of $20.6^{\circ} \mathrm{C}$ at Miskolc, the resulting $9.7^{\circ} \mathrm{C}$ are almost identical to the measured MAT of $9.8^{\circ} \mathrm{C}$, which provides evidence for the validity of the method and encourages a tentative application to the 5 paleotemperatures cited above. A MAT range of $9.2-9.9^{\circ} \mathrm{C}$ can be derived from the Hungarian mean July malacothermometer temperatures of $19-21^{\circ} \mathrm{C}$. The proposed temperatures for Tokaj, $14-18^{\circ} \mathrm{C}$ from the malacothermometer method and $18.0^{\circ} \mathrm{C}$ from $\delta^{13} \mathrm{C}$, result in a MAT of $7.4-8.8$ or $8.8^{\circ} \mathrm{C}$.

The regional temperature estimates from the literature largely correspond to our 20 data and converge towards a MAT of ca. $8^{\circ} \mathrm{C}$ for the period of $45-27 \mathrm{ka}$. However, these paleotemperature estimates are consistently higher than those proposed in large-scale paleoclimatic reconstructions as e.g. in the Paleoclimatic Atlas of the Northern Hemisphere with a MAT of $2-4^{\circ} \mathrm{C}$ and a mean July temperature of 14$16^{\circ} \mathrm{C}$ (Frenzel et al., 1992). Contradictions between proxy data and climate models 25 have been observed e.g. by Kageyama et al. (2006), Strandberg et al. (2011) and Mairesse et al. (2013). Among the factors discussed are e.g. a higher atmospheric and oceanic variability during the LGM, large uncertainty ranges in proxy data, a too coarse spatial resolution of model data, complex terrain and the sensitivity of regional climate to vegetation cover. Besides this deviation of model and proxy data, a higher

\section{CPD}

$10,469-507,2014$

\section{Paleoclimate and weathering of the \\ Tokaj loess-paleosol sequence}

A.-K. Schatz et al.

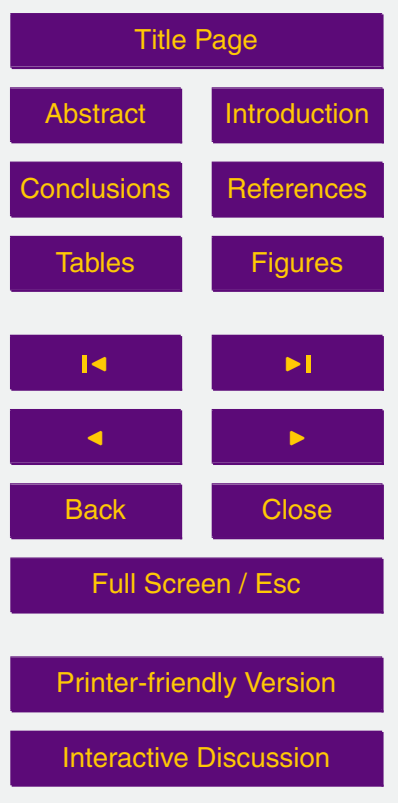

Interactive Discussion 
regional MAT in the Carpathian Basin would result in a very large climatic gradient between SE and NW Europe (e.g. MAT of $-2^{\circ} \mathrm{C}$, mean July temperature of $10^{\circ} \mathrm{C}$; Huijzer and Vandenberghe, 1998), which has recently been confirmed by Heyman et al. (2013) in their glacier modeling data. To clarify and further explore these 5 (apparent) contradictions, more and detailed quantitative data from different archives and proxies is needed.

\section{MAT during the time of dust deposition (27-21 ka)}

For the time of dust deposition in MIS 2, geochemistry-based XRF-1-MAT and XRF2MAT result in a temperature range of $8.5 \pm 0.6^{\circ} \mathrm{C}$ to $8.9 \pm 4.4^{\circ} \mathrm{C}$. MS-based MAT is 10 lower with a MAT of $6.7^{\circ} \mathrm{C}$ (Table 2, Fig. 4a). For the period of maximum cooling of the LGM (21 ka; Clark et al., 2009), regional mean annual temperatures of $2-3^{\circ} \mathrm{C}$ (Kovács et al., 2012), 0-4 ${ }^{\circ} \mathrm{C}$ (Hatté et al., 2013 and references therein), $3.3^{\circ} \mathrm{C}$ (Varsányi et al., 2011), $0.8^{\circ} \mathrm{C}$ (Corcho Alvarado et al., 2011) and $1^{\circ} \mathrm{C}$ (Stute and Deák, 1989) have been reported. These values are largely consistent with those from large-scale models, 15 e.g. $0-2{ }^{\circ} \mathrm{C}$ and a mean July temperature of $8-10^{\circ} \mathrm{C}$ (Frenzel et al., 1992), a MAT of $0{ }^{\circ} \mathrm{C}$ (Peyron et al., 1998) or a mean July temperature of $10^{\circ} \mathrm{C}$ (Kageyama et al., 2006). More recent climate modeling results show a cooling of $8-15^{\circ} \mathrm{C}$ for Central European upland regions (Heyman et al., 2013) and a global cooling of $1.9-9.1^{\circ} \mathrm{C}$ (Strandberg et al., 2011) or $5.8 \pm 1.4^{\circ} \mathrm{C}$ (Schneider von Deimling et al., 2006). An 20 atmospheric circulation model yields a MAT between 0 and $6{ }^{\circ} \mathrm{C}$ for the Carpathian Basin (Strandberg et al., 2011). Whereas some of these estimates are consistent with our data, most of them are slightly or considerably lower than our temperatures. However, we did not specifically sample the peak LGM loess layer, nor are we certain if our samples even include loess deposited during this specific cold peak, since OSL and $25 \mathrm{pIRIR}_{290}$ ages differ for the youngest loess of the section (Fig. 1b; Schatz et al., 2012). We therefore do not consider our results to be peak LGM temperatures but rather mean temperatures during dust deposition in MIS 2. Model and proxy temperature estimates for the peak LGM are accordingly considered as minimum temperatures.

\section{CPD}

$10,469-507,2014$

\section{Paleoclimate and weathering of the \\ Tokaj loess-paleosol sequence}

A.-K. Schatz et al.

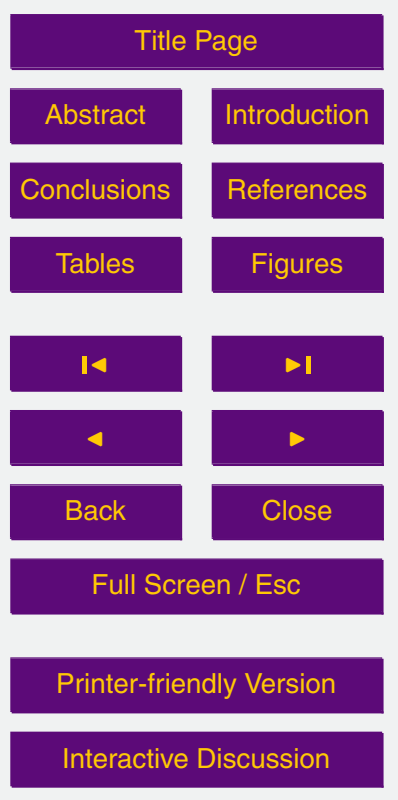


Regional temperature estimates for the MIS 2 before the LGM peak have been reconstructed from oxygen isotopes in mammoth tooth enamel (Kovács et al., 2012), ranging from $6.2^{\circ} \mathrm{C}$ to $11.2^{\circ} \mathrm{C}$ in the Czech Republic and Slovakia. Corcho Alvarado et al. (2011) report a MAT of $4.5^{\circ} \mathrm{C}$ using noble gas thermometry (NGT). Based on 5 the malacothermometer method, Novothny et al. (2011), Krolopp and Sümegi (1995) and Sümegi and Krolopp (2002) propose a mean July temperature of $11-13^{\circ} \mathrm{C}$ in Hungary, and generally cooler and drier temperatures compared to MIS 3. Sümegi and Hertelendi (1998) have reconstructed mean July temperatures of $12-16^{\circ} \mathrm{C}$ - related to topography and particularly aspect - for Tokaj. Using the conversion for mean

10 July temperatures (Hall and Penner, 2013), these malacothermometer results probably correspond to a Hungarian MAT range of $6.4-7.1^{\circ} \mathrm{C}$ and a Tokaj-specific MAT of 6.7$8.1^{\circ} \mathrm{C}$. Although there is singular evidence for permafrost activity in the region, which would require MAT to be as low as -12 to $-20^{\circ} \mathrm{C}$ (Kovács, 2007), the vast majority of studies conducted in the Carpathian Basin indicates that, on the contrary, the region 15 sustained milder climatic conditions than comparable latitudes further west and might have been a possible location for the hypothesized cold stage refugia of temperate flora and fauna (Fitzsimmons and Hambach, 2014; Willis et al., 2000; Willis and van Andel, 2004).

Our MATs of $6.7^{\circ} \mathrm{C}(\mathrm{MS}), 8.5 \pm 0.6^{\circ} \mathrm{C}$ (XRF-1) and $8.9 \pm 4.4^{\circ} \mathrm{C}$ (XRF-2) seem to be 20 slightly too high although they are overall comparable with the literature data, especially the MS-based MAT. The same problem with XRF-MAT has been observed by Kühn et al. (2013) who considered the temperatures calculated for loess as too high, but the temperatures calculated from the paleosols as plausible.

\subsubsection{Mean annual precipitation (MAP)}

25 Current mean annual precipitation (MAP) of the region around Tokaj is $546 \mathrm{mma}^{-1}$ (1991-2000 average, Miskolc, World Data Center for Meteorology, 2011). Quantitative regional paleoprecipitation estimates from the literature are scarce. There seems to

\section{CPD}

$10,469-507,2014$

\section{Paleoclimate and weathering of the \\ Tokaj loess-paleosol sequence}

A.-K. Schatz et al.

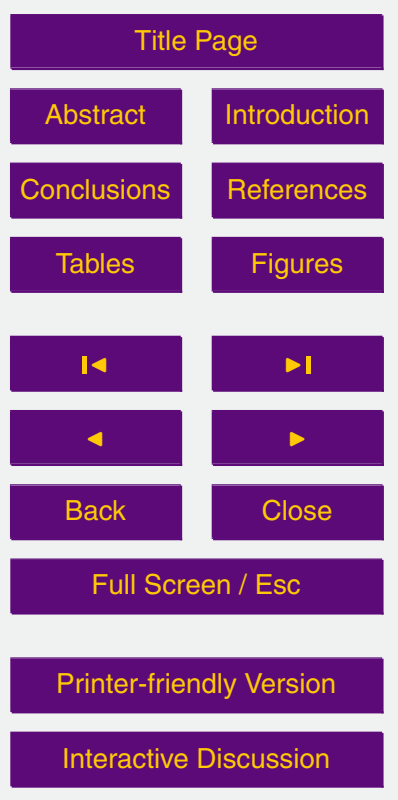


be an agreement on the fact that MIS 3 was wetter, while MIS 2 was dry or very dry (Fitzsimmons et al., 2012; and all malacology studies cited above).

For the paleosol, our MS-based MAP are 325 and $441 \mathrm{mma}^{-1}$, depending on the empirical formula used. XRF-based MAP results in $685-785 \mathrm{mma}^{-1}$ (XRF2-MAP, 5 XRF1-MAP; Table 2, Fig. 4b). The use of XRF2-MAP is only recommended for mollisols, but still included for comparison. Frenzel et al. (1992) suggest a MAP range of $250-450 \mathrm{mma}^{-1}$ for SE Europe. Hatté and Guiot (2005) report $400 \mathrm{mma}^{-1}$ for the loess section at Nussloch, SW Germany, based on carbon isotopes. A similar range of 450-850 $\mathrm{mma}^{-1}$ has been proposed by Kühn et al. (2013) for Alsheim (Mainz Basin), SW Germany, using the same geochemical transfer functions as in this study.

For the loess layer, our XRF data result in a range of $572-687 \mathrm{mma}^{-1}$, while the MS-MAP is again lower (224 $\mathrm{mma}^{-1}$; Table 2, Fig. 4b). Frenzel et al. (1992) propose a range of $50-450 \mathrm{mma}^{-1}$ for the LGM. Peyron et al. (1998) suggest a decrease of $800 \mathrm{mma}^{-1}$ compared to modern MAP, which would result in negative values 15 for our data. Hatté and Guiot (2005) report $200 \mathrm{mma}^{-1}$ for Nussloch and Kühn et al. (2013) 300-400 $\mathrm{mma}^{-1}$ for Alsheim. Specifically for the LGM in upland regions, Heyman et al. (2013) propose a precipitation decrease of $25-75 \%$. Strandberg et al.'s (2011) European circulation model indicates a decrease in precipitation of about $300 \mathrm{mma}^{-1}$, but with substantial regional variations. Fitzsimmons and Hambach (2014, and references therein) suggest a decrease of about $60 \%$ for the Carpathian Basin based on a review of other studies.

For both paleosol and loess samples, our MS-MAT is consistent with the literature values, whereas XRF1- and XRF2-MAT are probably too high. XRF2-MAT has the lowest values, which might still be acceptable; however, caution is required when using the formula since it is only intended for mollisols. As discussed for MAT above, the paleoclimate in the Carpathian Basin was probably spatially highly diverse and differed from the surrounding regions. Large-scale models may not (yet) be able to express these heterogeneous conditions in their predicted MATs and MAPs, a fact that is also reflected in the wide range of predicted model MAPs in the literature. Consequently, the

\section{CPD}

$10,469-507,2014$

\section{Paleoclimate and weathering of the \\ Tokaj loess-paleosol sequence}

A.-K. Schatz et al.

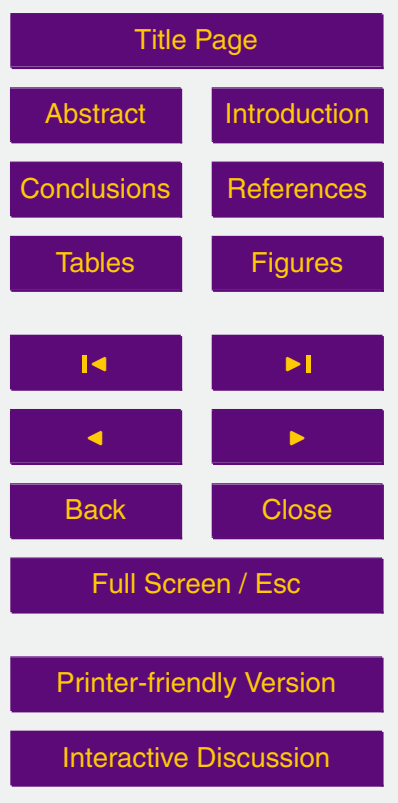


results from large-scale models for specific locations tend to differ from those obtained by local proxy reconstructions.

\section{Summary and conclusions}

We calculated and compared 14 Wls from loess and paleosol samples from the upper 5 part of the Tokaj profile. The results are basically similar and show almost no variation with depth for the different WIs, leading us to the conclusion that restricting the choice of suitable weathering indices to those containing only a few elements (e.g. CPA, as proposed by Buggle et al., 2011) is probably overcautious and potentially introduces additional sources of error, mainly effects of recent weathering processes and soil 10 formation like accumulation of salts under dry climate conditions. We recommend to calculate a selection of weathering indices from different generic groups, i.e. multielement, trace-element, Ca-free, K-free, evaluate their sensitivity towards changes in weathering intensity and compare the results; if similar, it is not necessary to present more than one index in the publication.

15 The paleoclimate of NE Hungary was described by MAT and MAP. MAT was calculated based on XRF, $\delta^{13} \mathrm{C}$ and MS data. For the time of soil formation (45-27 ka), XRF-, MS- and $\delta^{13} \mathrm{C}$-based results converge to a MAT of $8-10^{\circ} \mathrm{C}$, similar to, or slightly lower than today. This temperature range corresponds to the majority of the literature data for the region, but is systematically higher than proposed by large-scale climate models, which are probably not (yet) able to reflect the highly diverse paleoclimate of the Carpathian Basin. The locally reconstructed paleoclimate data may serve to refine these models. For the time of dust deposition (27-21 ka), XRF-based MAT results in a temperature range of $8-9^{\circ} \mathrm{C}$, which is probably too high, compared to other loess studies. Agreement with the literature data is best achieved with the MS-based MAT of $256.7^{\circ} \mathrm{C}$.

For MAP we estimate a range of $685-879 \mathrm{mma}^{-1}$ for the time of paleosol formation using XRF transfer functions. MS-based results are consistently lower $\left(325-441 \mathrm{mma}^{-1}\right)$. For the time of loess deposition, both XRF- and MS-based

\section{CPD}

$10,469-507,2014$

\section{Paleoclimate and weathering of the \\ Tokaj loess-paleosol sequence}

A.-K. Schatz et al.

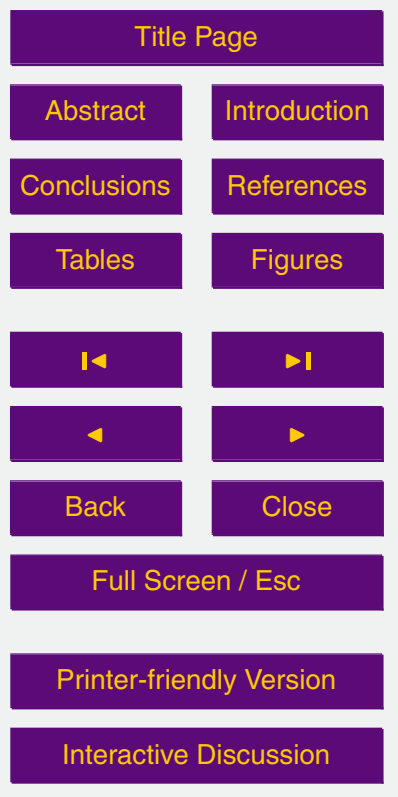

Interactive Discussion 
results are significantly lower with $572-700 \mathrm{mma}^{-1}$ and $224 \mathrm{mma}^{-1}$. MS-based MAP reconstructions are generally consistent with the literature, whereas most XRF-based results are probably too high.

\section{Supplementary material related to this article is available online at 5 http://www.clim-past-discuss.net/10/469/2014/cpd-10-469-2014-supplement. pdf.}

Acknowledgements. This research was funded by a graduation fellowship from the state of Baden-Wuerttemberg, Germany. We acknowledge financial support from the Open Access Publishing Fund of the University of Tübingen. The authors would like to thank Pál Sümegi 10 (University of Szeged, Hungary) for his support during the field trip and an introduction to the site, M. Zech, B. Buggle (University of Bayreuth, Germany), S. Gulyás, G.D. Páll and G. Persaits (University of Szeged) for help with field work and H. Taubald and team (University of Tübingen, Germany) for XRF measurements.

\section{References}

15 An, Z., Liu, T., Lu, Y., Porter, S. C., Kukla, G., Wu, X., and Hua, Y.: The long-term paleomonsoon variation recorded by the loess-paleosol sequence in Central China, Quatern. Int., 7-8, 9195, doi:10.1016/1040-6182(90)90042-3, 1990.

Baumann, F., Kühn, P., Dörfer, C., Schmidt, K., He, J.-S., and Scholten, T.: Pedogenesis, permafrost, substrate and topography: plot and landscape scale interrelations of weathering processes on the central-eastern Qinghai-Tibet Plateau, Geoderma, in review, 2014.

Buggle, B., Hambach, U., Glaser, B., Gerasimenko, N., Marković, S., Glaser, I., and Zöller, L.: Stratigraphy, and spatial and temporal paleoclimatic trends in Southeastern/Eastern European loess-paleosol sequences, Quatern. Int., 196, 86-106, doi:10.1016/j.quaint.2008.07.013, 2009.

25 Buggle, B., Glaser, B., Hambach, U., Gerasimenko, N., and Marković, S.: An evaluation of geochemical weathering indices in loess-paleosol studies, Quatern. Int., 240, 12-21, doi:10.1016/j.quaint.2010.07.019, 2011.

\section{CPD}

$10,469-507,2014$

\section{Paleoclimate and weathering of the \\ Tokaj loess-paleosol sequence}

A.-K. Schatz et al.

\section{Title Page}


Catt, J. A.: Soils as indicators of quaternary climatic change in mid-latitude regions, Geoderma, 51, 167-187, doi:10.1016/0016-7061(91)90070-A, 1991.

Catt, J. A., Kemp, R., Felix-Henningsen, P., and Scholten, T.: Recent and paleo-pedogenesis as tools for modelling past and future global change, preface, Catena, 41, 1-2, doi:10.1016/S0341-8162(00)00101-6, 2000.

Chen, J., An, Z., and Head, J.: Variation of Rb/Sr ratios in the loess-paleosol sequences of central China during the last 130000 years and their implications for monsoon paleoclimatology, Quaternary Res., 51, 215-219, doi:10.1006/qres.1999.2038, 1999.

Clark, P. U., Dyke, A. S., Shakun, J. D., Carlson, A. E., Clark, J., Wohlfarth, B., Mitrovica, J. X., Hostetler, S. W., and McCabe, A. M.: The Last Glacial Maximum, Science, 325, 710-714, doi:10.1126/science.1172873, 2009.

Corcho Alvarado, J. A., Leuenberger, M., Kipfer, R., Paces, T., and Purtschert, R.: Reconstruction of past climate conditions over central Europe from groundwater data, Quaternary Sci. Rev., 30, 3423-3429, doi:10.1016/j.quascirev.2011.09.003, 2011.

Cullers, R. L.: The geochemistry of shales, siltstones and sandstones of PennsylvanianPermian age, Colorado, USA: implications for provenance and metamorphic studies, Lithos, 51, 181-203, doi:10.1016/S0024-4937(99)00063-8, 2000.

Darmody, R. G., Thorn, C. E., and Allen, C. E.: Chemical weathering and boulder mantles, Kärkevagge, Swedish Lapland, Geomorphology, 67, 159-170, 20 doi:10.1016/j.geomorph.2004.07.011, 2005.

Dultz, S.: Veränderung des mineralogischen Stoffbestandes in Böden aus pleistozänen Sedimenten Nordwestdeutschlands und deren Bedeutung für die Elementfreisetzung, Berichte des Forschungszentrums Waldökosysteme, Reihe A, Göttingen, Germany, 201 pp., 2001.

Evans, M. E. and Heller, F.: Magnetism of loess/palaeosol sequences: recent developments, Earth-Sci. Rev., 54, 129-144, doi:10.1016/S0012-8252(01)00044-7, 2001.

Fedo, C. M., Nesbitt, H. W., and Young, G. M.: Unraveling the effects of potassium metasomatism in sedimentary rocks and paleosols, with implications for paleoweathering conditions and provenance, Geology, 23, 921-924, doi:10.1130/00917613(1995)023<0921:uteopm>2.3.co;2, 1995.

Feng, Z.-D.: Geochemical characteristics of a loess-soil sequence in central Kansas, Soil Sci. Soc. Am. J., 61, 534-541, doi:10.2136/sssaj1997.03615995006100020023x, 1997.

\section{CPD}

10, 469-507, 2014

\section{Paleoclimate and weathering of the \\ Tokaj loess-paleosol sequence}

A.-K. Schatz et al.

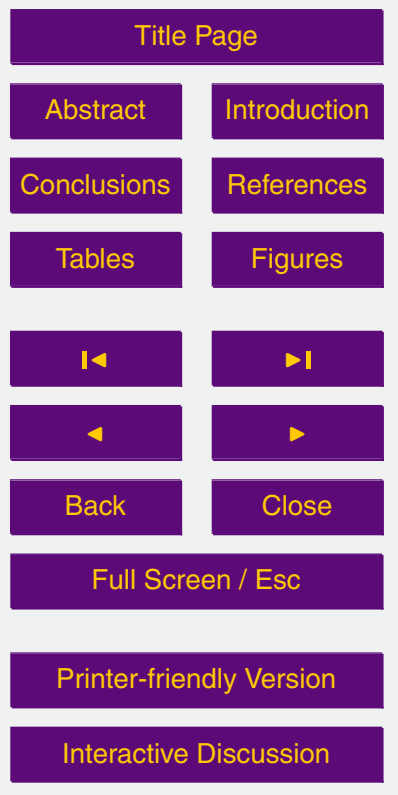


Fiedler, H. J., Talheim, K., Hofmann, W., Hunger, W., and Ilgen, G.: Chemische Zusammensetzung von Böden über unterschiedlichen Grundgesteinen des Osterzgebirges, Chem. Erde-Geochem., 50, 269-277, 1990 (in German).

Fitzsimmons, K. E. and Hambach, U.: Loess accumulation during the last glacial maximum: evidence from Urluia, southeastern Romania, Quatern. Int., doi:10.1016/j.quaint.2013.08.005, in press, 2014.

Fitzsimmons, K. E., Marković, S. B., and Hambach, U.: Pleistocene environmental dynamics recorded in the loess of the middle and lower Danube basin, Quaternary Sci. Rev., 41, 104118, doi:10.1016/j.quascirev.2012.03.002, 2012.

10 Frenzel, B., Pécsi, M., and Velichko, A. A.: Atlas of Paleoclimates and Paleoenvironments of the Northern Hemisphere, Late Pleistocene-Holocene, Geographical Institute, Hungarian Academy of Sciences and Gustav Fischer Verlag, Budapest, Stuttgart, 1992.

Gallagher, T. M. and Sheldon, N. D.: A new paleothermometer for forest paleosols and its implications for Cenozoic climate, Geology, 41, 647-650, doi:10.1130/g34074.1, 2013.

15 Gallet, S., Jahn, B.-M., and Torii, M.: Geochemical characterization of the Luochuan loesspaleosol sequence, China, and paleoclimatic implications, Chem. Geol., 133, 67-88, doi:10.1016/S0009-2541(96)00070-8, 1996.

Garrels, R. M. and Mackenzie, F. T.: Evolution of Sedimentary Rocks, Norton, New York, 1971.

Goldberg, K. and Humayun, M.: The applicability of the Chemical Index of Alteration as 20 a paleoclimatic indicator: an example from the Permian of the Paraná Basin, Brazil, Palaeogeogr. Palaeocl., 293, 175-183, doi:10.1016/j.palaeo.2010.05.015, 2010.

Gromet, L. P., Haskin, L. A., Korotev, R. L., and Dymek, R. F.: The "North American shale composite": its compilation, major and trace element characteristics, Geochim. Cosmochim. Ac., 48, 2469-2482, doi:10.1016/0016-7037(84)90298-9, 1984.

Hall, S. A. and Penner, W. L.: Stable carbon isotopes, C3-C4 vegetation, and 12800 years of climate change in central New Mexico, USA, Palaeogeogr. Palaeocl., 369, 272-281, doi:10.1016/j.palaeo.2012.10.034, 2013.

Han, J., Lü, H., Wu, N., and Guo, Z.: The magnetic susceptibility of modern soils in China and its use for paleoclimate reconstruction, Stud. Geophys. Geod., 40, 262-275, doi:10.1007/BF02300742, 1996.

Harnois, L.: The CIW index: a new chemical index of weathering, Sediment Geol., 55, 319-322, doi:10.1016/0037-0738(88)90137-6, 1988.
CPD

10, 469-507, 2014

\section{Paleoclimate and weathering of the \\ Tokaj loess-paleosol sequence}

A.-K. Schatz et al.

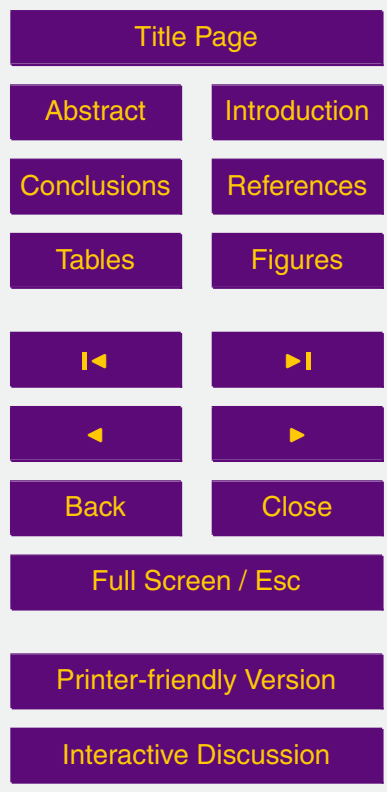


Hatté, C. and Guiot, J.: Palaeoprecipitation reconstruction by inverse modelling using the isotopic signal of loess organic matter: application to the Nußloch loess sequence (Rhine Valley, Germany), Clim. Dynam., 25, 315-327, doi:10.1007/s00382-005-0034-3, 2005.

Hatté, C., Antoine, P., Fontugne, M., Rousseau, D.-D., Tisnérat-Laborde, N., and Zöller, L.: New 5 chronology and organic matter $\delta^{13} \mathrm{C}$ paleoclimatic significance of Nußloch loess sequence (Rhine Valley, Germany), Quatern. Int., 62, 85-91, doi:10.1016/S1040-6182(99)00026-9, 1999.

Hatté, C., Gauthier, C., Rousseau, D.-D., Antoine, P., Fuchs, M., Lagroix, F., Marković, S. B., Moine, O., and Sima, A.: Excursions to $\mathrm{C}_{4}$ vegetation recorded in the Upper Pleistocene loess of Surduk (Northern Serbia): an organic isotope geochemistry study, Clim. Past, 9, 1001-1014, doi:10.5194/cp-9-1001-2013, 2013.

Heyman, B. M., Heyman, J., Fickert, T., and Harbor, J. M.: Paleo-climate of the central European uplands during the last glacial maximum based on glacier mass-balance modeling, Quaternary Res., 79, 49-54, doi:10.1016/j.yqres.2012.09.005, 2013.

Huijzer, B. and Vandenberghe, J.: Climatic reconstruction of the Weichselian Pleniglacial in northwestern and Central Europe, J. Quaternary Sci., 13, 391-417, doi:10.1002/(SICI)10991417(1998090)13:5<391::AID-JQS397>3.0.CO;2-6, 1998.

Hungarian Meteorological Service: Climate Data Series 1901-2000, http://www.met.hu/en/ eghajlat/magyarorszag_eghajlata/eghajlati_adatsorok_1901-2000/, last access: 30 January 2014, 2013.

Kageyama, M., Laîné, A., Abe-Ouchi, A., Braconnot, P., Cortijo, E., Crucifix, M., de Vernal, A., Guiot, J., Hewitt, C. D., Kitoh, A., Kucera, M., Marti, O., Ohgaito, R., OttoBliesner, B., Peltier, W. R., Rosell-Melé, A., Vettoretti, G., Weber, S. L., and Yu, Y.: Last Glacial Maximum temperatures over the North Atlantic, Europe and western Siberia: a comparison between PMIP models, MARGO sea-surface temperatures and pollen-based reconstructions, Quaternary Sci. Rev., 25, 2082-2102, doi:10.1016/j.quascirev.2006.02.010, 2006.

Kemp, R. A.: Pedogenic modification of loess: significance for palaeoclimatic reconstructions, Earth-Sci. Rev., 54, 145-156, doi:10.1016/S0012-8252(01)00045-9, 2001.

30 Kovács, J.: Chemical weathering intensity of the Late Cenozoic "Red Clay" deposits in the Carpathian Basin, Geochem. Int+., 45, 1056-1063, doi:10.1134/S0016702907100096, 2007.

\section{CPD}

$10,469-507,2014$

\section{Paleoclimate and weathering of the \\ Tokaj loess-paleosol sequence}

A.-K. Schatz et al.

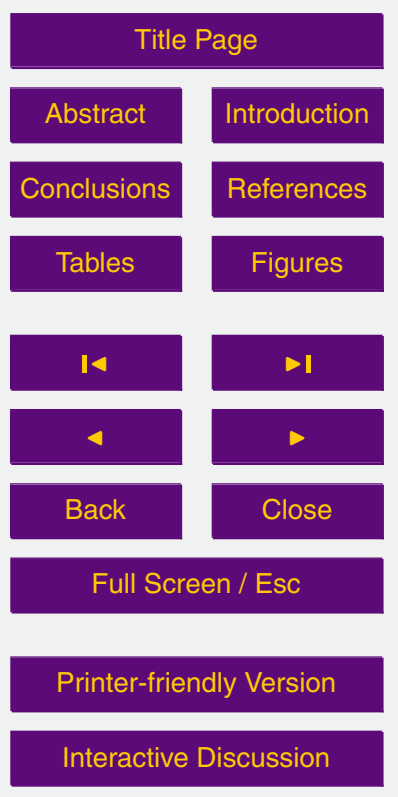


Kovács, J., Moravcová, M., Újvári, G., and Pintér, A. G.: Reconstructing the paleoenvironment of East Central Europe in the Late Pleistocene using the oxygen and carbon isotopic signal of tooth in large mammal remains, Quatern. Int., 276-277, 145-154, doi:10.1016/j.quaint.2012.04.009, 2012.

5 Krolopp, E. and Sümegi, P.: Palaeoecological reconstruction of the late pleistocene, based on loess malacofauna in Hungary, GeoJournal, 36, 213-222, doi:10.1007/BF00813173, 1995.

Kronberg, B. I. and Nesbitt, H. W.: Quantification of weathering, soil geochemistry and soil fertility, J. Soil Sci., 32, 453-459, doi:10.1111/j.1365-2389.1981.tb01721.x, 1981.

Kühn, P.: Spätglaziale und holozäne Lessivégenese auf jungweichselzeitlichen Sedimenten 10 Deutschlands, in: Greifswalder Geographische Arbeiten, Geographisches Institut der ErnstMoritz-Arndt-Universität Greifswald, Germany, Greifswald, 205 pp., 2003 (in German).

Kühn, P., Techmer, A., and Weidenfeller, M.: Lower to middle Weichselian pedogenesis and palaeoclimate in Central Europe using combined micromorphology and geochemistry: the loess-paleosol sequence of Alsheim (Mainz Basin, Germany), Quaternary Sci. Rev., 75, 43-

$15 \quad$ 58, doi:10.1016/j.quascirev.2013.05.019, 2013.

$\mathrm{Li}, \mathrm{C}$. and Yang, S.: Is chemical index of alteration $(\mathrm{CIA})$ a reliable proxy for chemical weathering in global drainage basins?, Am. J. Sci., 310, 111-127, doi:10.2475/02.2010.03, 2010.

Lu, H., Huissteden, K. V., An, Z., Nugteren, G., and Vandenberghe, J.: East Asia winter monsoon variations on a millennial time-scale before the last glacial-interglacial cycle, J. Quaternary Sci., 14, 101-110, doi:10.1002/(SICI)1099-1417(199903)14:2<101::AIDJQS433>3.0.CO;2-M, 1999.

Maher, B. A., Thompson, R., and Zhou, L. P.: Spatial and temporal reconstructions of changes in the Asian palaeomonsoon: a new mineral magnetic approach, Earth Planet. Sc. Lett., 125, 461-471, doi:10.1016/0012-821X(94)90232-1, 1994.

25 Mairesse, A., Goosse, H., Mathiot, P., Wanner, H., and Dubinkina, S.: Investigating the consistency between proxy-based reconstructions and climate models using data assimilation: a mid-Holocene case study, Clim. Past, 9, 2741-2757, doi:10.5194/cp-9-27412013, 2013.

Marbut, C. F.: Atlas of American Agriculture, Part III, Soils of the United States, 8th edn., Washington (D.C.), 1935.

CPD

10, 469-507, 2014

\section{Paleoclimate and weathering of the \\ Tokaj loess-paleosol sequence}

A.-K. Schatz et al.

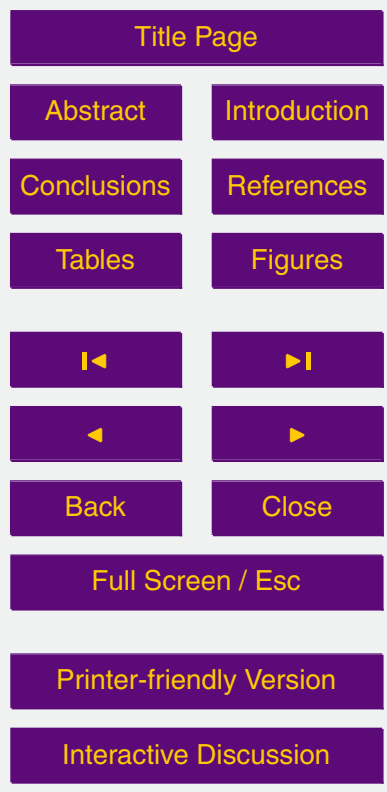


Marković, S. B., Oches, E. A., McCoy, W. D., Frechen, M., and Gaudenyi, T.: Malacological and sedimentological evidence for "warm" glacial climate from the Irig loess sequence, Vojvodina, Serbia, Geochem. Geophy. Geosy., 8, Q09008, doi:10.1029/2006GC001565, 2007.

Marković, S. B., Bokhorst, M. P., Vandenberghe, J., McCoy, W. D., Oches, E. A., Hambach, U., 5 Gaudenyi, T., Jovanović, M., Zöller, L., Stevens, T., and Machalett, B.: Late Pleistocene loesspalaeosol sequences in the Vojvodina region, north Serbia, J. Quaternary Sci., 23, 73-84, doi:10.1002/jqs.1124, 2008.

McLennan, S. M.: Weathering and global denudation, J. Geol., 101, 295-303, doi:10.1086/648222, 1993.

10 Meier, H. A., Driese, S. G., Nordt, L. C., Forman, S. L., and Dworkin, S. I.: Interpretation of Late Quaternary climate and landscape variability based upon buried soil macro- and micromorphology, geochemistry, and stable isotopes of soil organic matter, Owl Creek, central Texas, USA, Catena, 114, 157-168, doi:10.1016/j.catena.2013.08.019, 2014.

Muhs, D. R., Budahn, J. R., McGeehin, J. P., Bettis III, E. A., Skipp, G., Paces, J. B., and 15 Wheeler, E. A.: Loess origin, transport, and deposition over the past 10,000 years, WrangellSt. Elias National Park, Alaska, Aeol. Res., 11, 85-99, doi:10.1016/j.aeolia.2013.06.001, 2013.

Nesbitt, H. W. and Young, G. M.: Early Proterozoic climates and plate motions inferred from major element chemistry of lutites, Nature, 299, 715-717, doi:10.1038/299715a0, 1982.

20 Nesbitt, H. W. and Young, G. M.: Prediction of some weathering trends of plutonic and volcanic rocks based on thermodynamic and kinetic considerations, Geochim. Cosmochim. Ac., 48, 1523-1534, doi:10.1016/0016-7037(84)90408-3, 1984.

Nordt, L., von Fischer, J., and Tieszen, L.: Late Quaternary temperature record from buried soils of the North American Great Plains, Geology, 35, 159-162, doi:10.1130/g23345a.1, 252007.

Novothny, Á., Frechen, M., Horváth, E., Wacha, L., and Rolf, C.: Investigating the penultimate and last glacial cycles of the Süttõ loess section (Hungary) using luminescence dating, high-resolution grain size, and magnetic susceptibility data, Quatern. Int., 234, 75-85, doi:10.1016/j.quaint.2010.08.002, 2011.

30 Pécsi, M.: Quaternary and Loess Research, Akadémiai Kiadó, Budapest, Hungary, 1993.

Peyron, O., Guiot, J., Cheddadi, R., Tarasov, P., Reille, M., de Beaulieu, J.-L., Bottema, S., and Andrieu, V.: Climatic reconstruction in Europe for 18000 yr B.P. from pollen data, Quaternary Res., 49, 183-196, doi:10.1006/qres.1997.1961, 1998.

\section{CPD}

$10,469-507,2014$

\section{Paleoclimate and weathering of the \\ Tokaj loess-paleosol sequence}

A.-K. Schatz et al.

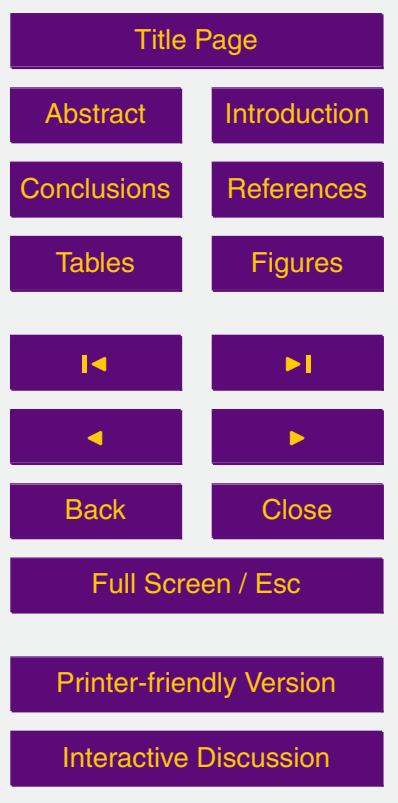


Pietsch, D. and Kühn, P.: Early Holocene paleosols at the southwestern Ramlat As-Sab'atayn desert margin: new climate proxies for southern Arabia, Palaeogeogr. Palaeocl., 365-366, 154-165, doi:10.1016/j.palaeo.2012.09.023, 2012.

Pietsch, D., Kühn, P., Lisitsyn, S., Markova, A., and Sinitsyn, A.: Krotovinas, pedogenic 5 processes and stratigraphic ambiguities of the Upper Palaeolithic sites Kostenki and Borshchevo (Russia), Quatern. Int., doi:10.1016/j.quaint.2013.05.036, in press, 2014.

Porter, S. C.: Chinese loess record of monsoon climate during the last glacial-interglacial cycle, Earth-Sci. Rev., 54, 115-128, doi:10.1016/S0012-8252(01)00043-5, 2001.

Retallack, G. J.: Soils of the Past, Blackwell, Oxford, 600 pp., 2001.

10 Rudner, Z. E. and Sümegi, P.: Recurring Taiga forest-steppe habitats in the Carpathian Basin in the Upper Weichselian, Quatern. Int., 76-77, 177-189, doi:10.1016/S1040-6182(00)001014, 2001.

Schatz, A.-K., Zech, M., Buggle, B., Gulyás, S., Hambach, U., Marković, S. B., Sümegi, P., and Scholten, T.: The late Quaternary loess record of Tokaj, Hungary: reconstructing palaeoenvironment, vegetation and climate using stable $\mathrm{C}$ and $\mathrm{N}$ isotopes and biomarkers, Quatern. Int., 240, 52-61, doi:10.1016/j.quaint.2010.10.009, 2011.

Schatz, A.-K., Buylaert, J.-P., Murray, A., Stevens, T., and Scholten, T.: Establishing a luminescence chronology for a palaeosol-loess profile at Tokaj (Hungary): a comparison of quartz OSL and polymineral IRSL signals, Quat. Geochronol., 10, 68-74, doi:10.1016/j.quageo.2012.02.018, 2012.

Schneider von Deimling, T., Ganopolski, A., Held, H., and Rahmstorf, S.: How cold was the Last Glacial Maximum?, Geophys. Res. Lett., 33, L14709, doi:10.1029/2006GL026484, 2006.

Sheldon, N. D.: Quaternary glacial-interglacial climate cycles in Hawaii, J. Geol., 114, 367-376, doi:10.1086/500993, 2006.

Sheldon, N. D. and Tabor, N. J.: Quantitative paleoenvironmental and paleoclimatic reconstruction using paleosols, Earth-Sci. Rev., 95, 1-52, doi:10.1016/j.earscirev.2009.03.004, 2009.

Sheldon, N. D., Retallack, G. J., and Tanaka, S.: Geochemical climofunctions from North American soils and application to Paleosols across the Eocene-Oligocene boundary in Oregon, J. Geol., 110, 687-696, doi:10.1086/342865, 2002.

30 Strandberg, G., Brandefelt, J., Kjellström, E., and Smith, B.: High-resolution regional simulation of last glacial maximum climate in Europe, Tellus A, 63, 107-125, doi:10.1111/j.16000870.2010.00485.x, 2011.

\section{CPD}

10, 469-507, 2014

\section{Paleoclimate and weathering of the \\ Tokaj loess-paleosol sequence}

A.-K. Schatz et al.

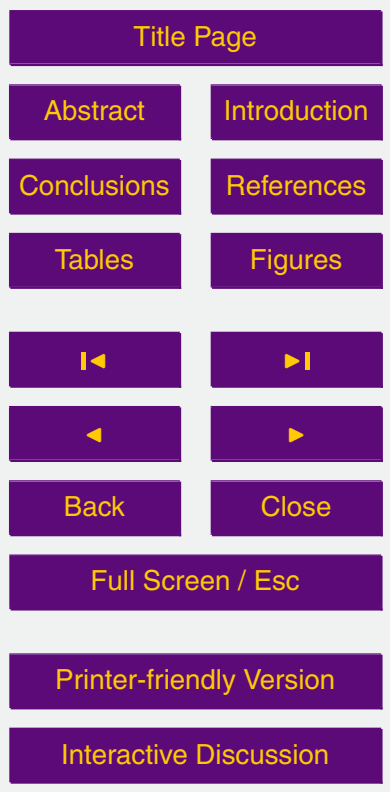


Stute, M. and Deák, J.: Environmental isotope study (14C, 13C, 18O, D, noble gases) on deep groundwater circulation systems in Hungary with reference to paleoclimate, Radiocarbon, 31, 902-918, 1989.

Sümegi, P. and Hertelendi, E.: Reconstruction of microenvironmental changes in the Kopasz 5 Hill loess area at Tokaj (Hungary) between 15 and 70 ka BP, Radiocarbon, 40, 855-863, 1998.

Sümegi, P. and Krolopp, E.: Quatermalacological analyses for modeling of the Upper Weichselian palaeoenvironmental changes in the Carpathian Basin, Quatern. Int., 91, 5363, doi:10.1016/S1040-6182(01)00102-1, 2002.

10 Sümegi, P. and Rudner, Z. E.: In situ charcoal fragments as remains of natural wild fires in the upper Würm of the Carpathian Basin, Quatern. Int., 76-77, 165-176, doi:10.1016/S10406182(00)00100-2, 2001.

Taylor, S. R. and McLennan, S. M.: The Continental Crust: Its Composition and Evolution, Blackwell Scientific Publications, Oxford, 1985.

15 Terhorst, B., Kühn, P., Damm, B., Hambach, U., Meyer-Heintze, S., and Sedov, S.: Paleoenvironmental fluctuations as recorded in the loess-paleosol sequence of the Upper Paleolithic site Krems-Wachtberg, Quatern. Int., doi:10.1016/j.quaint.2013.03.045, in press, 2014.

Újvári, G., Varga, A., and Balogh-Brunstad, Z.: Origin, weathering, and geochemical composition of loess in southwestern Hungary, Quaternary Res., 69, 421-437, doi:10.1016/j.yqres.2008.02.001, 2008.

Újvári, G., Varga, A., Raucsik, B., and Kovács, J.: The Paks loess-paleosol sequence: a record of chemical weathering and provenance for the last $800 \mathrm{ka}$ in the mid-Carpathian Basin, Quatern. Int., 319, 22-37, doi:10.1016/j.quaint.2012.04.004, 2014.

Vancampenhout, K., Langohr, R., Slaets, J., Buurman, P., Swennen, R., and Deckers, J.: Paleo-pedological record of the Rocourt Pedosequence at Veldwezelt-Hezerwater (Belgian Pleistocene loess belt): Part 1 - evolution of the parent material, Catena, 107, 118-129, doi:10.1016/j.catena.2013.02.005, 2013.

Varga, A., Újvári, G., and Raucsik, B.: Tectonic versus climatic control on the evolution 30 of a loess-paleosol sequence at Beremend, Hungary: an integrated approach based on paleoecological, clay mineralogical, and geochemical data, Quatern. Int., 240, 71-86, doi:10.1016/j.quaint.2010.10.032, 2011.

\section{CPD}

10, 469-507, 2014

\section{Paleoclimate and weathering of the \\ Tokaj loess-paleosol sequence}

A.-K. Schatz et al.

\section{Title Page}

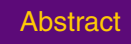

Introduction

Conclusions

Tables

References

Figures

14

4

Back

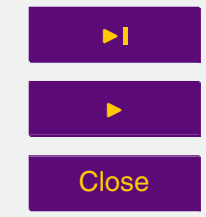

Full Screen / Esc

Printer-friendly Version

Interactive Discussion 
Varsányi, I., Palcsu, L., and Kovács, L. Ó.: Groundwater flow system as an archive of palaeotemperature: Noble gas, radiocarbon, stable isotope and geochemical study in the Pannonian Basin, Hungary, Appl. Geochem., 26, 91-104, doi:10.1016/j.apgeochem.2010.11.006, 2011.

5 Wedepohl, K. H.: Handbook of Geochemistry, Springer, Berlin, 1987.

Willis, K. J. and van Andel, T. H.: Trees or no trees? The environments of central and eastern Europe during the Last Glaciation, Quaternary Sci. Rev., 23, 2369-2387, doi:10.1016/j.quascirev.2004.06.002, 2004.

Willis, K. J., Rudner, E., and Sümegi, P.: The full-glacial forests of central and southeastern

10 Europe, Quaternary Res., 53, 203-213, doi:10.1006/qres.1999.2119, 2000.

World Data Center for Meteorology: 9th Series World Weather Records (WWR) 1991-2000, Asheville, 2011.

Xiao, S., Liu, W., Li, A., Yang, S., and Lai, Z.: Pervasive autocorrelation of the chemical index of alteration in sedimentary profiles and its palaeoenvironmental implications, Sedimentology,

15 57, 670-676, doi:10.1111/j.1365-3091.2009.01113.x, 2010.

Xiong, S., Ding, Z., Zhu, Y., Zhou, R., and Lu, H.: A 6 Ma chemical weathering history, the grain size dependence of chemical weathering intensity, and its implications for provenance change of the Chinese loess-red clay deposit, Quaternary Sci. Rev., 29, 1911-1922, doi:10.1016/j.quascirev.2010.04.009, 2010.

20 Yang, S., Ding, F., and Ding, Z.: Pleistocene chemical weathering history of Asian arid and semi-arid regions recorded in loess deposits of China and Tajikistan, Geochim. Cosmochim. Ac., 70, 1695-1709, doi:10.1016/j.gca.2005.12.012, 2006.

Zech, M., Zech, R., and Glaser, B.: A 240000 -year stable carbon and nitrogen isotope record from a loess-like palaeosol sequence in the Tumara Valley, Northeast Siberia, Chem. Geol., 242, 307-318, doi:10.1016/j.chemgeo.2007.04.002, 2007.

Zech, M., Zech, R., Zech, W., Glaser, B., Brodowski, S., and Amelung, W.: Characterisation and palaeoclimate of a loess-like permafrost palaeosol sequence in NE Siberia, Geoderma, 143, 281-295, doi:10.1016/j.geoderma.2007.11.012, 2008.

Zech, M., Andreev, A., Zech, R., Müller, S., Hambach, U., Frechen, M., and Zech, W.: in northeast Siberia using alkane biomarker and pollen analyses, Boreas, 39, 540-550, doi:10.1111/j.1502-3885.2009.00132.x, 2010.

CPD

$10,469-507,2014$

\section{Paleoclimate and weathering of the \\ Tokaj loess-paleosol sequence}

A.-K. Schatz et al.

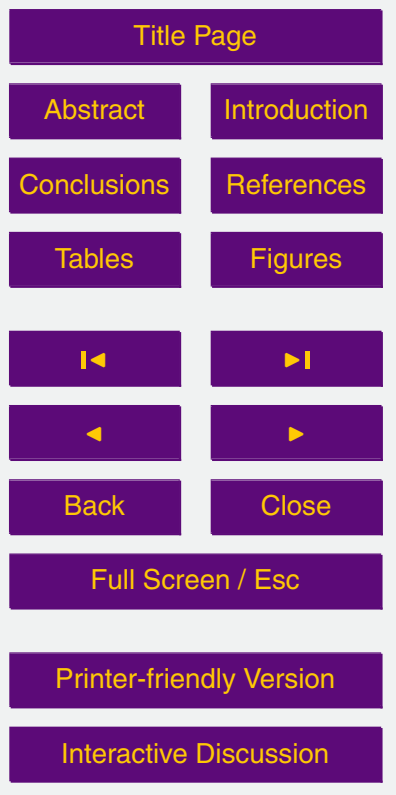

Interactive Discussion 
Table 1. Overview of weathering indices and empirical climate transfer functions for MAT, MAP and MJT (mean July temperature).

\begin{tabular}{|c|c|c|c|}
\hline \multicolumn{2}{|c|}{ Weathering index } & Equation & Reference \\
\hline multi-element & $\begin{array}{l}\text { CIA } \\
\text { Index A } \\
\text { Index B } \\
\text { PWI } \\
\text { EBases/Al }\end{array}$ & $\begin{array}{l}=\left[\mathrm{Al} /\left(\mathrm{Al}+\mathrm{Na}+\mathrm{Ca}^{*}+\mathrm{K}\right)\right] \cdot 100 \\
=\left(\mathrm{Si}+\mathrm{Ca}^{*}+\mathrm{K}+\mathrm{Na}\right) /\left(\mathrm{Al}+\mathrm{Si}+\mathrm{Ca}^{*}+\mathrm{K}+\mathrm{Na}\right) \\
=\left(\mathrm{Ca}^{*}+\mathrm{Na}+\mathrm{K}\right) /\left(\mathrm{Al}+\mathrm{Ca}^{*}+\mathrm{Na}+\mathrm{K}\right) \\
=[(4.20 \cdot \mathrm{Na})+(1.66 \cdot \mathrm{Mg})+(5.54 \cdot \mathrm{K})+(2.05 \cdot \mathrm{Ca})] \times 100 \\
=\left(\mathrm{Ca}^{*}+\mathrm{Mg}+\mathrm{Na}+\mathrm{K}\right) / \mathrm{Al}\end{array}$ & $\begin{array}{l}\text { Nesbitt and Young (1982) } \\
\text { Kronenberg and Nesbitt (1981) } \\
\text { Kronenberg and Nesbitt (1981) } \\
\text { Gallagher and Sheldon (2013) } \\
\text { Retallack (2001) }\end{array}$ \\
\hline K-free & $\begin{array}{l}\text { CIW (CIA-K) } \\
\text { PIA } \\
\text { YANG } \\
\text { WI-1 } \\
\text { WI-2 }\end{array}$ & $\begin{array}{l}=\left[\mathrm{Al} /\left(\mathrm{Al}+\mathrm{Na}+\mathrm{Ca}^{*}\right)\right] \times 100 \\
=\left[(\mathrm{Al}-\mathrm{K}) /\left(\mathrm{Al}+\mathrm{Ca}^{*}+\mathrm{Na}-\mathrm{K}\right)\right] \times 100 \\
=\left(\mathrm{Ca}^{*}+\mathrm{Na}+\mathrm{Mg}\right) / \mathrm{Ti} \\
=\left(\mathrm{Si}+\mathrm{Ca}^{*}\right) /(\mathrm{Fe}+\mathrm{Ti}) \\
=\left(\mathrm{Si}+\mathrm{Ca}^{*}\right) /(\mathrm{Fe}+\mathrm{Ti}+\mathrm{Al})\end{array}$ & $\begin{array}{l}\text { Harnois (1988), Maynard (1992) } \\
\text { Fedo et al. (1995) } \\
\text { Yang et al. (2006) } \\
\text { Darmody et al. (2005) } \\
\text { Darmody et al. (2005) }\end{array}$ \\
\hline $\begin{array}{l}\text { Ca-free } \\
\text { trace element }\end{array}$ & $\begin{array}{l}\text { CPA }\left(\mathrm{CIW}^{\prime}\right) \\
\mathrm{FENG} \\
\mathrm{Ba} / \mathrm{Sr} \\
\mathrm{Rb} / \mathrm{Sr}\end{array}$ & $\begin{array}{l}=[\mathrm{Al} /(\mathrm{Al}+\mathrm{Na})] \times 100 \\
=(\mathrm{Al}+\mathrm{Fe}) /(\mathrm{Na}+\mathrm{K}+\mathrm{Mg}+\mathrm{P})\end{array}$ & $\begin{array}{l}\text { Cullers (2000), Buggle (2011) } \\
\text { Feng (1997) }\end{array}$ \\
\hline & arameter & & \\
\hline XRF-based & $\begin{array}{l}\text { XRF1-MAP } \\
\text { XRF2-MAP }^{\mathrm{a}} \\
\text { XRF3-MAP } \\
\text { XRF1-MAT }^{\mathrm{b}} \\
\text { XRF2-MAT }^{\text {XRF3-MAT }}\end{array}$ & $\begin{array}{l}=-259.3 \ln \left(\sum \mathrm{Bases} / \mathrm{Al}\right)+759 \\
=-130.9 \ln (\mathrm{Ca} / \mathrm{Al})+467 \\
=221.1 e^{0.0179(\mathrm{ClA}-\mathrm{K})} \\
=46.9(\mathrm{Al} / \mathrm{Si})+4 \\
=-18.5 \cdot[(\mathrm{K}+\mathrm{Na}) / \mathrm{Al}]+17.3 \\
=-2.74 \ln (\mathrm{PWI})+21.39\end{array}$ & $\begin{array}{l}\text { Sheldon et al. (2002) } \\
\text { Sheldon et al. (2002) } \\
\text { Sheldon et al. (2002) } \\
\text { Sheldon (2006) } \\
\text { Sheldon et al. (2002) } \\
\text { Gallagher and Sheldon (2013) }\end{array}$ \\
\hline MS-based & $\begin{array}{l}\text { MS1-MAP } \\
\text { MS2-MAP }^{\mathrm{e}} \\
\text { MS-MAT }^{\mathrm{e}}\end{array}$ & $\begin{array}{l}=222+199 \log \left(X_{\mathrm{B}-\mathrm{C}}\right) \\
=-22.7+11.6 X-6.7 \times 10^{-2} X^{2}+1.9 \times 10^{-4} X^{3}-1.9 \times 10^{-7} X^{4} \\
=-2.4+0.2 X-1.1 \times 10^{-3} X^{2}+2.7 \times 10^{-6} X^{3}-2.7 \times 10^{-9} X^{4}\end{array}$ & $\begin{array}{l}\text { Maher et al. (1994) } \\
\text { Han et al. (1996) } \\
\text { Han et al. (1996) }\end{array}$ \\
\hline$\delta^{13} \mathrm{C}$-based & $\delta^{13} \mathrm{C}-\mathrm{MJT}^{f}$ & $=\left[0.685\left(\delta^{13} \mathrm{C}\right)+34.9\right]$ & Nordt et al. (2007) \\
\hline
\end{tabular}

a mollisols-specific

${ }^{b}$ inceptisol-specific

${ }^{\mathrm{c}}$ forest soil-specific

${ }^{\mathrm{d}} X_{\mathrm{B}-\mathrm{C}}=\left[(\right.$ mean MS of B horizon) $-($ mean MS of loess $)]$, MS $\left[10^{-8} \mathrm{~m}^{3} \mathrm{~kg}^{-1}\right]$

${ }^{\mathrm{e}} X=$ mean $\mathrm{MS}$ of $\mathrm{B}$ horizon or loess

${ }^{f}$ the $\delta^{13} \mathrm{C}$ transfer function results in a mean July paleotemperature (MJT) which needs to be converted to MAT (see Sect. 5.3.1 for details).

\section{CPD}

$10,469-507,2014$

\section{Paleoclimate and weathering of the Tokaj loess-paleosol sequence}

A.-K. Schatz et al.

\section{Title Page}

\section{Abstract}

Introduction

Conclusions

References

Tables

Figures

14

4

Back

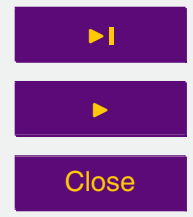

Full Screen / Esc

Printer-friendly Version

Interactive Discussion 
Table 2. Overview of weathering index results. Arrows indicate if an index increases or decreases with increasing weathering intensity. $\mathrm{CaO}^{*}$ and $\mathrm{CaO}^{* *}$ denote the type of $\mathrm{CaO}$ correction (see text). The $\mathrm{min} / \mathrm{max}$ values obtained for the study area are shown, together with results from previous studies at other locations: ${ }^{a}$ loess from southwest Hungary (Újvári et al., 2008), ' loess from Paks, Hungary (Újvári et al., 2014), ' ${ }^{\mathrm{C}}$ loess from Stari Slankamen, Serbia (Buggle et al., 2011), ${ }^{d}$ loess from Beremend, Hungary (Varga et al., 2011), ${ }^{\mathrm{e}}$ Average Loess Composition (AVL ${ }^{3}$, Újvári et al., 2008), ${ }^{f}$ Red Clay from SW Hungary (Kovacs, 2007). Caution is required when comparing Wls in absolute numbers because results differ depending on the $\mathrm{CaO}$ correction used.

\begin{tabular}{|c|c|c|c|c|c|c|c|c|c|}
\hline Index & $\uparrow \downarrow$ & $\mathrm{CaO}$ & $\begin{array}{l}\text { Results } \\
\mathrm{min} / \mathrm{max}\end{array}$ & $\begin{array}{c}\text { Loess }^{a} \\
\mathrm{HU}\end{array}$ & $\begin{array}{c}\text { Loess }^{b} \\
\mathrm{HU}\end{array}$ & $\begin{array}{c}\text { Loess }^{c} \\
\text { RSB }\end{array}$ & $\begin{array}{c}\text { Loess }^{d} \\
\mathrm{HU}\end{array}$ & $\begin{array}{l}\mathrm{AVL}^{3 e} \\
\text { global }\end{array}$ & $\begin{array}{c}\text { Red Clay } \\
\text { HU }\end{array}$ \\
\hline \multirow[t]{2}{*}{$\mathrm{CIA}$} & $\uparrow$ & $\mathrm{CaO}^{*}$ & $49-67$ & - & - & - & - & - & 79.3 \\
\hline & & $\mathrm{CaO}^{* *}$ & 57-67 & $58-66$ & $60-70$ & $57-76$ & $67-78$ & 41 & - \\
\hline \multirow{2}{*}{ Index A } & $\downarrow$ & $\mathrm{CaO}^{*}$ & $0.91-0.923$ & - & - & - & - & - & - \\
\hline & & $\mathrm{CaO}^{* *}$ & $0.91-0.923$ & - & - & - & - & 0.922 & - \\
\hline \multirow[t]{2}{*}{ Index B } & $\downarrow$ & $\mathrm{CaO}^{*}$ & $0.33-0.51$ & - & - & - & - & - & - \\
\hline & & $\mathrm{CaO}^{* *}$ & $0.33-0.43$ & - & - & $0.24-0.43$ & - & 0.59 & - \\
\hline \multirow[t]{2}{*}{ PWI } & $\downarrow$ & $\mathrm{CaO}^{*}$ & $11.6-13.4$ & - & - & - & - & - & - \\
\hline & & $\mathrm{CaO}^{* *}$ & $11.6-13.4$ & - & - & - & - & 11.9 & - \\
\hline \multirow[t]{2}{*}{$\Sigma$ Bases/Al } & $\downarrow$ & $\mathrm{CaO}^{*}$ & $0.76-1.5$ & - & - & - & - & - & - \\
\hline & & $\mathrm{CaO}^{* *}$ & $0.75-1.18$ & - & - & - & - & 1.94 & - \\
\hline \multirow[t]{2}{*}{ CIW } & $\uparrow$ & $\mathrm{CaO}^{*}$ & 54-75 & - & - & - & - & - & - \\
\hline & & $\mathrm{CaO}^{* *}$ & $64-75$ & - & $67-80$ & $64-86$ & $76-88$ & 45 & - \\
\hline \multirow[t]{2}{*}{ PIA } & $\uparrow$ & $\mathrm{CaO}^{*}$ & $48-72$ & - & - & - & - & - & - \\
\hline & & $\mathrm{CaO}^{* *}$ & 59-72 & - & - & 60-85 & - & 39 & - \\
\hline \multirow[t]{2}{*}{ YANG } & $\downarrow$ & $\mathrm{CaO}^{*}$ & $6.4-14$ & - & $6-23$ & - & - & - & - \\
\hline & & $\mathrm{CaO}^{* *}$ & $6.3-10.6$ & - & - & - & - & 22 & - \\
\hline \multirow[t]{2}{*}{ WI-1 } & $\downarrow$ & $\mathrm{CaO}^{*}$ & $31-36$ & - & - & - & - & - & - \\
\hline & & $\mathrm{CaO}^{* *}$ & $31-35$ & - & - & - & - & 41 & - \\
\hline \multirow[t]{2}{*}{ WI-2 } & $\downarrow$ & $\mathrm{CaO}^{*}$ & 7.3-8.7 & - & - & - & - & - & - \\
\hline & & $\mathrm{CaO}^{* *}$ & 7.3-8.7 & - & - & - & - & 9 & - \\
\hline CPA & $\uparrow$ & & $78-83$ & - & 81-89 & $78-91$ & $86-94$ & 81 & - \\
\hline FENG & $\uparrow$ & & $1.3-1.9$ & - & - & - & - & 1.34 & - \\
\hline $\mathrm{Ba} / \mathrm{Sr}$ & $\uparrow$ & & $1.5-2.5$ & $2.1-2.8$ & $1.0-3.7$ & $1.0-3.2$ & $1.0-5.0$ & 1.3 & 1.1 \\
\hline $\mathrm{Rb} / \mathrm{Sr}$ & $\uparrow$ & & $0.51-0.87$ & $0.2-0.7$ & $0.2-0.9$ & $0.4-1.2$ & $0.3-1.4$ & 0.38 & 0.46 \\
\hline
\end{tabular}

CPD

$10,469-507,2014$

\section{Paleoclimate and weathering of the Tokaj loess-paleosol sequence}

A.-K. Schatz et al.

\section{Title Page}

Abstract Introduction

Conclusions References

Tables Figures

14

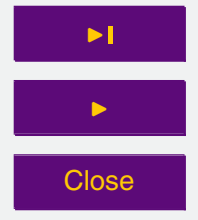

Back

\section{Full Screen / Esc}

Printer-friendly Version

Interactive Discussion 
CPD

$10,469-507,2014$

Paleoclimate and weathering of the Tokaj loess-paleosol sequence

\begin{tabular}{lllcc}
\hline Method & & $\mathrm{CaO}$ & Loess & Paleosol \\
\hline geochemistry-based & XRF1-MAP & $\mathrm{CaO}^{*}$ & 687 & 785 \\
& & $\mathrm{CaO}^{* *}$ & 729 & 798 \\
& XRF2-MAP & $\mathrm{CaO}^{*}$ & 572 & 685 \\
& $\mathrm{CaO}^{* *}$ & 644 & 708 \\
& XRF3-MAP & $\mathrm{CaO}^{*}$ & 700 & 879 \\
& & $\mathrm{CaO}^{* *}$ & 811 & 912 \\
& XRF1-MAT & - & $8.5 \pm 0.6$ & $8.8 \pm 0.6$ \\
& XRF2-MAT & - & $8.9 \pm 4.4$ & $9.9 \pm 4.4$ \\
& XRF3-MAT & $\mathrm{CaO}^{*}$ & 14.4 & 14.5 \\
& & $\mathrm{CaO}^{* *}$ & 14.4 & 14.5 \\
\hline MS-based & MS1-MAP & - & - & 441 \\
& MS2-MAP & - & 224 & 325 \\
& MS-MAT & - & 6.7 & 8.4 \\
\hline$\delta^{13}$ C-based & $\delta^{13} \mathrm{C}-\mathrm{MAT}$ & - & - & 8.8 \\
\hline
\end{tabular}

Table 3. Mean annual temperature (MAT, ${ }^{\circ} \mathrm{C}$ ) and mean annual precipitation (MAP, $\mathrm{mma}^{-1}$ ) for the Tokaj loess-paleosol profile. Equations are listed in Table 1.

A.-K. Schatz et al.

Title Page

Abstract

Introduction

Conclusions

References

Tables

Figures

14

4

Back

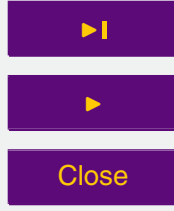

Full Screen / Esc

Printer-friendly Version

Interactive Discussion 


\section{CPD}

$10,469-507,2014$

\section{Paleoclimate and weathering of the \\ Tokaj loess-paleosol sequence}

Table 4. Correlation matrix of all weathering indices computed in this study $(n=35)$. The main group of weathering indices is highly correlated (CIA, CIA-K, CALMAG, PIA, Index B, ( $\Sigma$ Bases/Al), YANG, FENG, Ba/Sr, Rb/Sr). The Si-based subgroup (WI-1, WI-2, Index A) differs slightly; CPA and PWI are least correlated with all other indices.

\begin{tabular}{|c|c|c|c|c|c|c|c|c|c|c|c|c|c|c|c|}
\hline PWI & CPA & $\begin{array}{c}\text { Index } \\
\mathrm{A}\end{array}$ & WI-2 & WI-1 & $\begin{array}{c}\mathrm{Rb} / \\
\mathrm{Sr}\end{array}$ & $\begin{array}{c}\mathrm{Ba} / \\
\mathrm{Sr}\end{array}$ & FENG & YANG & $\begin{array}{c}\text { ¿Bases/ } \\
\mathrm{Al}\end{array}$ & $\begin{array}{c}\text { Index } \\
B\end{array}$ & PIA & $\begin{array}{l}\text { CAL- } \\
\text { MAG }\end{array}$ & CIA-K & $\mathrm{CIA}$ & \\
\hline-0.31 & 0.52 & -0.62 & -0.56 & -0.66 & 0.86 & 0.92 & 0.91 & -0.99 & -0.99 & -0.99 & 1.00 & 0.99 & 0.99 & 1.00 & $\mathrm{ClA}$ \\
\hline-0.30 & 0.52 & -0.63 & -0.61 & -0.67 & 0.88 & 0.92 & 0.91 & -0.99 & -0.99 & -0.99 & 1.00 & 0.99 & 1.00 & & CIA-K \\
\hline-0.30 & 0.52 & -0.63 & -0.60 & -0.66 & 0.88 & 0.92 & 0.91 & -0.99 & -0.99 & -0.99 & 1.00 & & & & PIA \\
\hline 0.31 & -0.52 & 0.61 & 0.59 & 0.65 & -0.87 & -0.92 & -0.92 & 0.99 & 0.99 & 1.00 & & & & & Index B \\
\hline 0.33 & -0.55 & 0.64 & 0.61 & 0.67 & -0.90 & -0.94 & -0.94 & 0.99 & 1.00 & & & & & & $\Sigma$ Bases/Al \\
\hline-0.40 & 0.65 & -0.72 & -0.72 & -0.76 & 0.97 & 1.00 & & & & & & & & & $\mathrm{Ba} / \mathrm{Sr}$ \\
\hline-0.51 & 0.76 & -0.81 & -0.81 & -0.85 & 1.00 & & & & & & & & & & $\mathrm{Rb} / \mathrm{Sr}$ \\
\hline 0.63 & -0.88 & 0.95 & 0.96 & 1.00 & & & & & & & & & & & WI-1 \\
\hline 0.60 & -0.88 & 0.99 & 1.00 & & & & & & & & & & & & WI-2 \\
\hline 0.63 & -0.90 & 1.00 & & & & & & & & & & & & & Index A \\
\hline-0.89 & 1.00 & & & & & & & & & & & & & & CPA \\
\hline 1.00 & & & & & & & & & & & & & & & PWI \\
\hline
\end{tabular}

A.-K. Schatz et al.

\section{Title Page}

Abstract

Introduction

Conclusions

References

Tables

Figures

14

4

Back

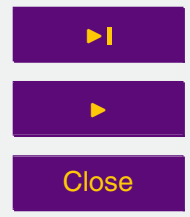

Full Screen / Esc

Printer-friendly Version

Interactive Discussion 
Table 5. Correlation chart of climate and weathering proxy data and weathering indices: stable $\mathrm{C}$ and $\mathrm{N}$ isotopes $\left(\delta^{13} \mathrm{C}, \delta^{15} \mathrm{~N}\right)$, mass-specific magnetic susceptibility (MS), percentage of grains $>30 \mu \mathrm{m}$ (grain size), percentage of shrubs and trees compared to grassland based on alkane biomarkers (\%trees); all data published in Schatz et al. (2011). Highest correlation coefficients are marked in bold print. FENG overall correlates best with the proxy records (mean $r=0.71$ ); CIA-K has the lowest correlation coefficient (mean $r=0.57$ ). Emphasis is given to MS and GS since they are probably most directly linked to climate; highest correlation coefficients with MS and GS are found for FENG and $\mathrm{Rb} / \mathrm{Sr}$, as well as for $\mathrm{Ba} / \mathrm{Sr}$ (MS) and WI-1 (GS).

\begin{tabular}{lccccc}
\hline & $\delta^{15} \mathrm{~N}$ & $\delta^{13} \mathrm{C}$ & $\mathrm{MS}$ & $\mathrm{GS}$ & \%trees \\
\hline CIA & 0.481 & 0.364 & 0.712 & 0.726 & 0.623 \\
CIA-K & 0.474 & 0.362 & 0.704 & 0.719 & 0.608 \\
CALMAG & 0.470 & 0.360 & 0.702 & 0.714 & 0.642 \\
PIA & 0.483 & 0.364 & 0.711 & 0.726 & 0.616 \\
Index B & 0.484 & 0.376 & 0.716 & 0.727 & 0.630 \\
IBases/Al & 0.493 & 0.392 & 0.749 & 0.745 & $\mathbf{0 . 6 7 6}$ \\
YANG & 0.486 & 0.383 & 0.753 & 0.731 & 0.628 \\
FENG & 0.657 & 0.455 & $\mathbf{0 . 8 6 5}$ & $\mathbf{0 . 8 6 9}$ & $\mathbf{0 . 6 9 8}$ \\
Ba/Sr & 0.623 & 0.452 & $\mathbf{0 . 7 9 6}$ & 0.814 & $\mathbf{0 . 6 6 9}$ \\
Rb/Sr & $\mathbf{0 . 6 7 8}$ & $\mathbf{0 . 4 9 6}$ & $\mathbf{0 . 8 5 1}$ & $\mathbf{0 . 8 5 1}$ & 0.618 \\
WI-1 & $\mathbf{0 . 7 2 5}$ & $\mathbf{0 . 4 7 5}$ & 0.785 & $\mathbf{0 . 8 5 6}$ & 0.362 \\
WI-2 & 0.654 & 0.411 & 0.701 & 0.787 & 0.380 \\
Index A & 0.674 & 0.440 & 0.716 & 0.789 & 0.425 \\
CPA & $\mathbf{0 . 7 2 9}$ & $\mathbf{0 . 4 6 3}$ & 0.787 & 0.823 & 0.376 \\
PWI & 0.621 & 0.373 & 0.684 & 0.661 & 0.238 \\
\hline
\end{tabular}



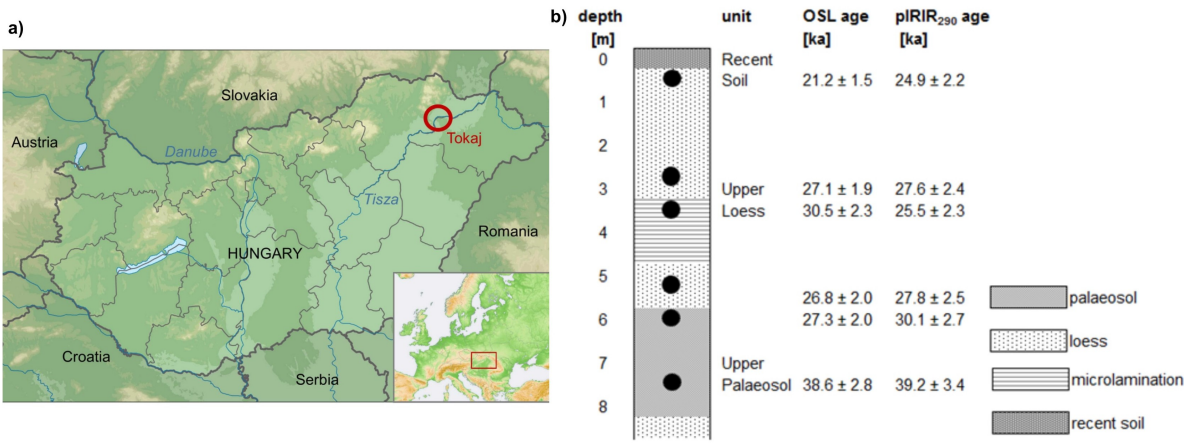

CPD

$10,469-507,2014$

\section{Paleoclimate and weathering of the Tokaj loess-paleosol sequence}

A.-K. Schatz et al.

Title Page

Abstract

Introduction

Conclusions

References

Tables

Figures

Fig. 1. (a) Map of the study area, Tokaj in NE Hungary. (b) Chronostratigraphy of the upper half of the paleosol-loess profile at Tokaj (Schatz et al., 2012).

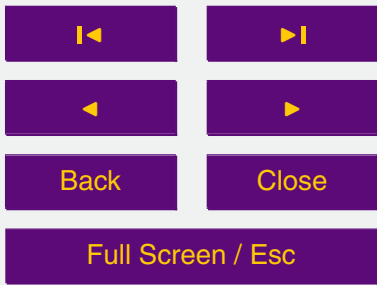

Printer-friendly Version

Interactive Discussion 

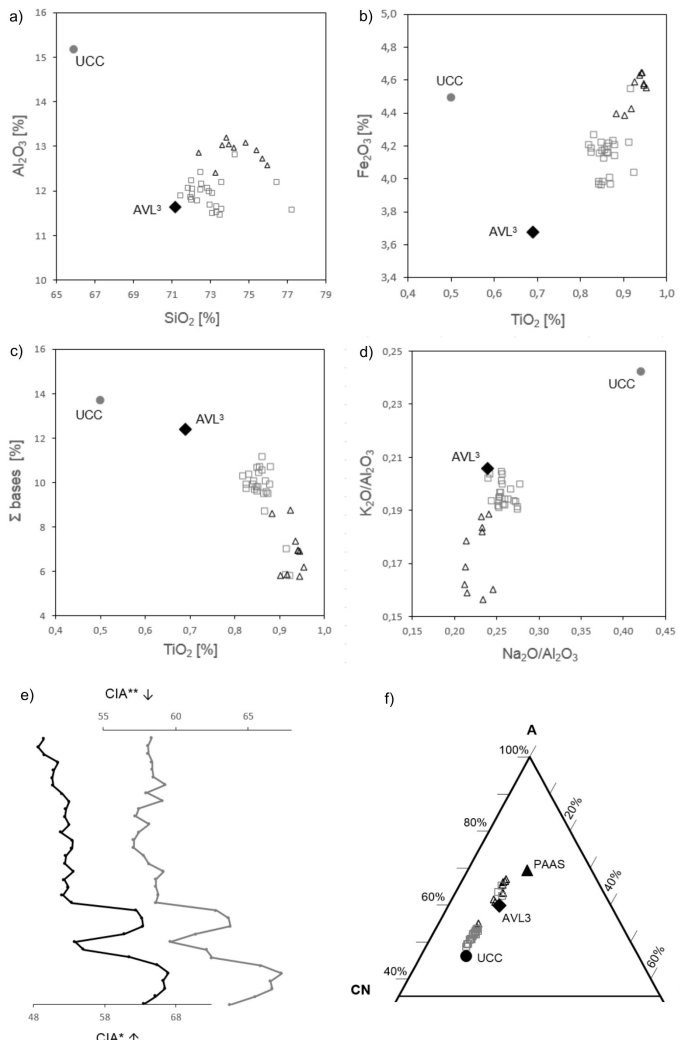

CN

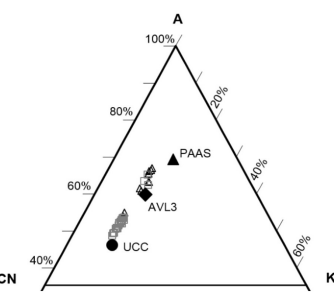

Title Page

Abstract

Introduction

Conclusions

References

Tables

Figures

Fig. 2. (a-d) $\mathrm{Al}_{2} \mathrm{O}_{3} / \mathrm{SiO}_{2}$ [wt.- $\%$ ], $\mathrm{Fe}_{2} \mathrm{O}_{3} / \mathrm{TiO}_{2}$ [wt.-\%], $\Sigma$ Bases $/ \mathrm{TiO}_{2}$ [wt.-\%], and $\mathrm{Na}_{2} \mathrm{O} / \mathrm{Al}_{2} \mathrm{O}_{3}$ vs. $\mathrm{K}_{2} \mathrm{O} / \mathrm{Al}_{2} \mathrm{O}_{3}$ [mol] plots illustrate geochemical weathering behavior. Grey open squares denote loess, black open triangles paleosol samples from Tokaj. The composition of the upper continental crust (UCC, Taylor and McLennan, 1985) and of average loess ( $\mathrm{AVL}^{3}$, Ujvari et al., 2008) are indicated for comparison. See text for details. (e) Comparison of the CIA weathering index computed with $\mathrm{CaO}^{*}$ (corrected via measured $\mathrm{CaCO}_{3}$ content and $\mathrm{TIC}$ ) and based on $\mathrm{CaO}^{* *}$ (corrected after McLennan, 1993). (f) Ternary A-CN-K diagram of the Tokaj paleosol and loess samples, UCC, $A V L^{3}$ and post-Archean Australian shale (PAAS, Taylor and McLennan, 1985). The samples plot parallel to the A-CN join, following an ideal weathering trend from less weathered UCC to highly weathered PAAS.

\section{4}

4

Back

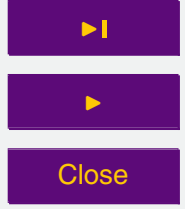

Full Screen / Esc

Printer-friendly Version

Interactive Discussion 


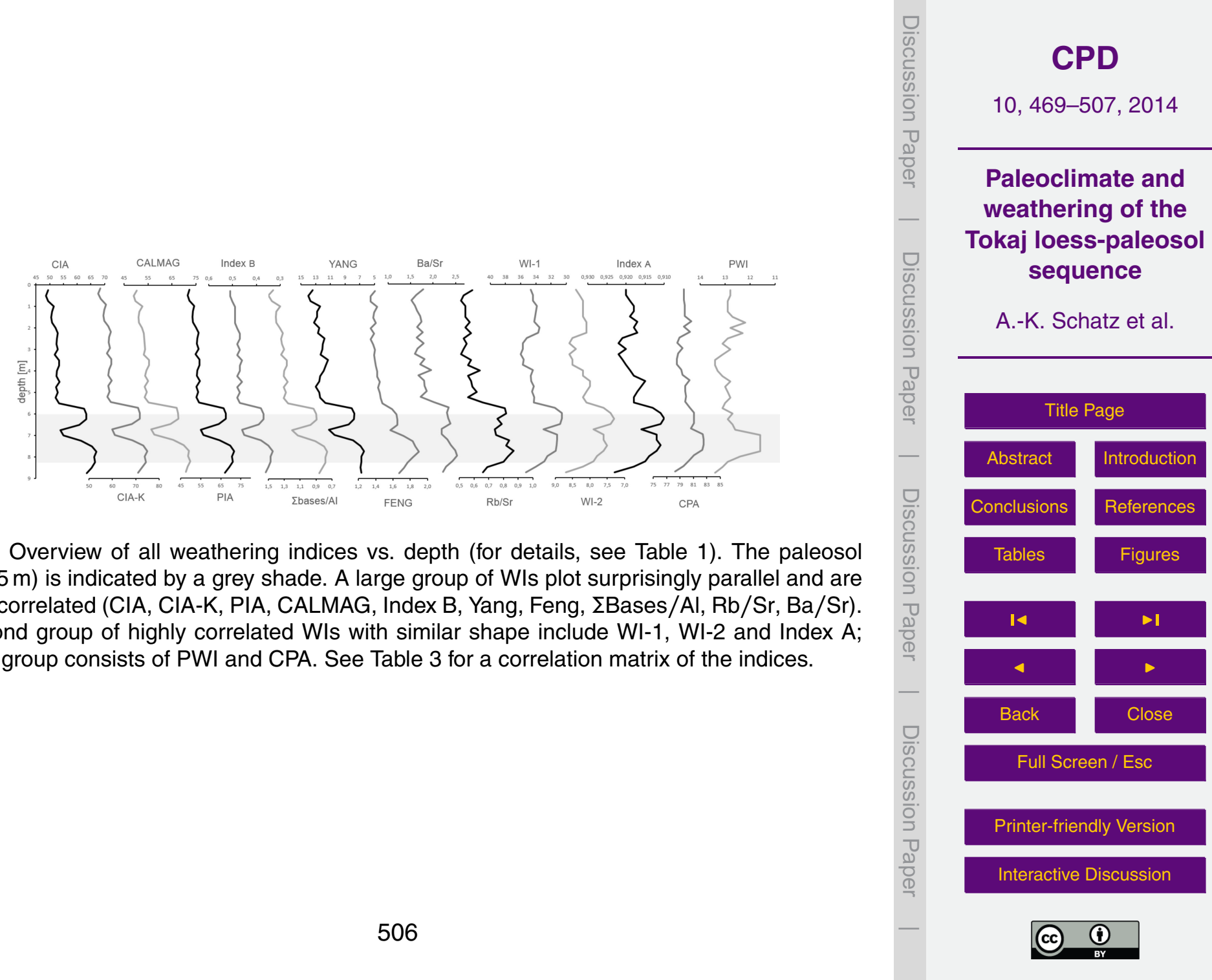



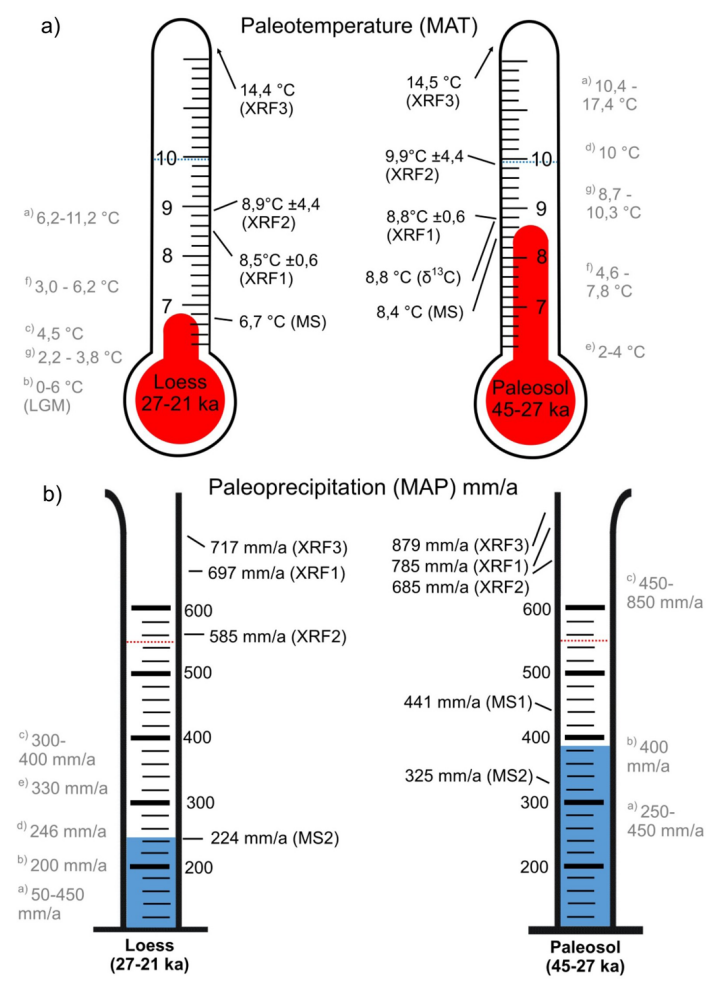

CPD

10, 469-507, 2014

\section{Paleoclimate and weathering of the Tokaj loess-paleosol sequence}

A.-K. Schatz et al.

\section{Title Page}

Abstract

Introduction

Conclusions

References

Tables Figures

14

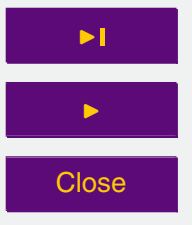

Back

Close  details): ${ }^{a}$ Kovács et al. (2012), ${ }^{b}$ Strandberg et al. (2011), ${ }^{c}$ Corcho Alvarado et al. (2011), ${ }^{\text {d }}$ e.g. Krolopp and Sümegi (1995), ${ }^{e}$ Frenzel et al. (1992), ${ }^{f}$ Sümegi and Hertelendi (1998), ${ }^{g}$ e.g. Sümegi and Krolopp (2002). (b) Reconstructed mean annual precipitation for loess and paleosol based on geochemical data (XRF1-MAP, XRF2-MAP, XRF3-MAP) and magnetic susceptibility (MS1-MAP, MS2-MAP). Red dotted lines denote present MAP $\left(550 \mathrm{mma}^{-1}\right)$. Selected regional precipitation estimates from the literature are shown for comparison: ${ }^{a}$ Frenzel et al. (1992), ${ }^{b}$ Hatté and Guiot (2005), ${ }^{\mathrm{c}}$ Kühn et al. (2013), ${ }^{\mathrm{d}}$ Fitzsimmons and Hambach (2013), ${ }^{\text {e }}$ Strandberg et al. (2011). 